\title{
CICERO'S LISTS OF TOPICS FROM ANTIQUITY TO THE EARLY MIDDLE AGES
}

\author{
Listado de tópicos en Cicerón desde la Antigüedad hasta la Alta Edad Media
}

\author{
Fiorella Magnano \\ Pontifical Lateran University Città del Vaticano
}

\begin{abstract}
Beginning with the Ciceronian divisions of rhetorical and dialectical topics as found, respectively, in the De inventione ( $84 \mathrm{BC}$ ), the De oratore (55 BC), the Partitiones oratoriae (54 BC) and the Topica (44 BC), the purpose of this study is to collect all the lists that have been transmitted from Antiquity to the early Middle Ages in order to observe - mainly through the help of several diagrams put in the appendix - their alteration, as well as their preservation.
\end{abstract}

Key words: Cicero, Boethius, Dialectics, Rhetoric, Topics

\section{RESUMEN}

A partir de las divisiones ciceronianas de los tópicos retóricos y dialécticos, que se encuentran, respectivamente, en el De inventione ( $84 \mathrm{BC}$ ), en el De oratore (55 BC), en las Partitiones Oratoriae (54 BC) y en los Topica (44 BC), el propósito de este estudio consiste en recoger todas las listas que han sido transmitidas desde la antigüedad hasta la Alta Edad Media con el fin de observar, con la ayuda de los distintos diagramas dispuestos en el Apéndice, tanto su alteración, como su conservación.

Palabras clave: Cicerón, Boecio, Dialéctica, Retórica, Tópica

\section{INTRODUCTION}

In the Academy founded by Plato (387-361 B.C.), the most important skill any student could acquire was the ability to defeat an interlocutor using only the power of reasoning. The dialectical debate had, therefore, its own specific feature: the ability to argue for or against a certain thesis arising from any question posed. As it is well known, Aristotle was the first to find a method that would enable a dialectician to identify the solution to any kind of question. The main instruments of this method were the tópoi (in Latin loci), where a tópos, according to Brunschwig, can be understood as a «machine for making premises starting from a given conclusion», or more simply, according to Sara Rubinelli, «an argument scheme of universal applicability». ${ }^{1}$ While the history of the reception of Aristotle's Topica in the Greek tradition

1 See Brunschwig, J., «Introduction», in Aristote: Topiques I-IV, texte etabli et traduit par J. Brunschwig, Paris, Librairie philosophique J. Vrin, 1967, p. xxxIx; Rubinelli, R., Ars topica. The Classical Technique of Constructing Arguments from Aristotle to Cicero, Lugano, Springer, 2009, pp. 12-21. For a recent bibliography on Aristotle's Topica see: Slomkowski, P., Aristotle's Topics, Leiden-New York-Köln, Brill, 1997. See also Perelman, C. «La Méthode dialectique et le rôle de l'interlocuteur dans le dialogue», in Revue de Métaphysique et de Morale, 60 (1955), pp. 26-31; Ross, W. D., «The Text of Aristotle's Topics and Sophistici Elenchi», in Mélanges de philosophie grecque offerts à Mgr. Diès, Paris, Adolf M. Hakkert, 1956; Owen, G. E. L. (ed.), Aristotle on Dialectic. 
still remains obscure to contemporary scholars, it is almost indisputable that the introduction of the Aristotelian topical system into the Latin tradition must be attributed to Cicero. ${ }^{2}$ Having come into contact with some texts related to the dialectical tradition of Aristotle's tópoi, or perhaps even the rhetorical tradition as well, Cicero completely reformed the loci rhetorici first elaborated upon in his early work, De inventione (around 84 B.C.), i.e., the attributes of person (persona) and act (negotium) ${ }^{3}$ In his latter works-viz., De oratore (55 B.C.), Partitiones oratoriae (54 B.C.), and the Topica (44 B.C.) - Cicero offered a new list of topics having a universal value, due to the fact that they were meant as instruments useful not only for Rhetoric or Law, but for every kind of disputatio. ${ }^{4}$

The differences between the attributes of person and act in the De inventione, on the one hand, and the loci of the later texts, on the other, are noteworthy (see Appendix, Diagrams 1-4). In the De inventione, the person (persona) is the subject brought to trial, whose deed or speech is censured, while the act (negotium) is the person's deed or speech for which he is brought to trial. Thus, discovering the material of an argument for an orator involves the examination of all the attributes related to the person and the act. ${ }^{5}$ There are eleven attributes, including also circumstances, concerning the person: name (nomen), nature (natura), way of life (victus), fortune (fortuna), disposition (habitus), feeling (affectio), studies (studia), purposes (consilia), deeds (facta), luck (casus), and discourses (oratio$n e s)$. The attributes of act are divided into four groups: (1) coherent with the act itself (continentia cum ipso negotio), (2) involved in the performance of the act (in gestione negotii), (3) adjuncts of the act (adiuncta negotio), (4) and consequent to the act (quae negotio con-

Proceedings of the Third Symposium Aristotelicum, Oxford, Clarendon, 1968; Thionville, E., De la théorie des lieux communs dans les Topiques d'Aristote, Osnabruck, O. Zeller, 1965; De Pater, W. A., Les Topiques d'Aristote et la dialectique platonicienne: la méthodologie de la définition, (Études thomistiques, 10), Fribourg, St. Paul, 1965; id., «La fonction du lieu et de l'instrument dans les Topiques», in G. E. L. Owen (ed.), Aristotle on Dialectic, o.c., pp. 164-188; Pinborg, J., «Topik un Syllogistik im Mittealter», in Sapienter Ordinare: Festgabe für Erich Kleineidam, (Erfurter theologische Studien, 24), Leipzig, St. Benno Verlag, 1969, pp. 157-178.

2 For a general overview on the Rhetoric into the Roman tradition and in the Middle Ages see: McKeon, P., «Rhetoric in the Middle Ages», in Speculum, 17 (1942), pp. 1-32; id., «Methods of Rhetorical and Philosophical Invention and Judgment», in L. Wallach (ed.), The Classical Tradition: Literary and Historical Studies in Honor of Harry Caplan, Ithaca-New York, Cornell University Press, 1966, pp. 365-373; ID., «The Hellenistic and Roman Foundation of the Tradition of Aristotle in the West», in Review of Metaphysic, 32-4 (1979), pp. 677-715; Plebe, A., Breve storia della retorica antica, Bari, Laterza, 1968; Kennedy, G., The Art of Rhetoric in the Roman World, 300 B.C.A.D. 300, Princeton, Princeton University Press, 1972; Ward, J. O., Artificiosa eloquentia in the Middle Ages, 2 vols, Diss., Toronto, University of Toronto, 1972; Murphy, J. J., Rhetoric in the Middle Ages. A History of Rhetorical Theory from Saint Augustin to the Renaissance, Berkeley - Los Angeles, University of California Press, 1974.

3 See Marcus Tullius Cicero, Rhetorici libri duo qui vocantur de inventione [= De inventione], E. Stroebel (ed.), (M. Tulli Ciceronis scripta quae manserunt omnia, 2), Stuttgart, B. G. Teubner, 1955, I, XXIV-XXVIII; id., De Oratore, K. F. Kumaniecki (ed.), (M. Tulli Ciceronis scripta quae manserunt omnia, 3), Stuttgart, B. G. Teubner, 1969, II, 162-173; id., Partitiones oratoriae, R. Giomini (ed.), (Bibliotheca scriptorum Latinorum 5), Roma, Herder, 1996, 5-8; id., Topica, ed. with a transl., introd. and commentary by T. Reinhardt, Oxford, Oxford University Press, 2003, §§ 6-24 and $\S$ 72-78, pp. 118-126 and 154-158.

4 See Cicero, De Oratore, II, 41, p. 175, 6-7: «His igitur locis in mente et cogitatione defixis et in omni re ad dicendum posita excitatis, nihil erit quod oratorem effugere possit, non modo in forensibus disceptationibus, sed omnino in ullo genere dicendi»; id., Partitiones oratoriae, 5, p. 390, 6: «Cicero: quid est argumentum?; Pater: Probabile inventum ad faciendam fidem»; Topica, 79, p. 158, 10-14: «Expositis omnibus argumentandi locis primum illud intellegendum est nec ullam esse disputationem in quam non aliquis locus incurrat nec fere omnis locos incidere in omnem quaestionem et quibusdam quaestionibus alios quibusdam alios esse aptiores locos».

5 See Cicero, De inventione, I, xxiv, 34, p. 31, 26-27: «Omnes res argumentando confirmatur aut ex eo, quod personis, aut ex eo, quod negotiis est adtributum». 
sequuntur). All these attributes are understood by Cicero as topics in a material sense, since they refer essentially to the matter of a rhetorical argument, i.e. to its content. ${ }^{6}$

On the contrary, in the De oratore, Partitiones oratoriae, and Topica, a locus is defined as the foundation of argument, and an argument is defined as a reason-producing belief in something which is in doubt. ${ }^{7}$ Here the topics seem to work on a higher level than that of the attributes, as they help the orator to discover the form rather than the matter to be assigned to one's own argument. According to Cicero, there are two species of topics: the first are artificiales, and they are intrinsic to the question in doubt (i.e., they are attached to the subject under discussion which needs to be confirmed). Indeed, the orator must have the ability to discover the most appropriate topic for each kind of particular cause. ${ }^{8}$ The second category of loci are called inartificiales as they are extrinsic to the issue and are entirely based on the authority, which ultimately relies upon divine and human testimony. ${ }^{9}$ Despite Cicero's intellectual development and shift concerning the theory of topics, both lists (those of the De inventione as well as of the Topica) continued to be transmitted, although modified from their original form. Therefore, beginning from these two Ciceronian divisions of topics, the purpose of this study is to collect all the lists which have been transmitted from antiquity until the early Middle Ages, in order to observe, with the assistance of the diagrams found in the Appendix, their alteration as well as their preservation. ${ }^{10}$

6 See Leff, M. C., «The Topics of Argumentative Invention in Latin Rhetorical Theory from Cicero to Boethius», in Rhetorica, 1 (1983), pp. 23-44; Michel, A., Les Rapports de la rhétorique et de la philosophie dans l'oeuvre de Cicéron, Paris, Presses Universitaires de France, 1960; ID., Rhétorique et philosophie chez. Cicéron: essai sur les fondements philosophiques de l'art de persuader, Paris, Presses Universitaires de France, 1961; Greco, M., «Introduzione», in M.T. Cicerone, De inventione, M. Greco (ed.), Galatina, 1998, pp. $5-53$.

7 See Cicero, De oratore, II, 162, p. 170, 17-18: «qui illi sedes et quasi domicilia omnium argumentorum commonstret et ea breviter inlustret verbisque definiat»; id., Topica, 7-8, p. 118, 21-28: «Ut igitur earum rerum quae absconditae sunt demonstrato et notato loco facilis inventio est, sic cum pervestigare argumentum aliquod volumus, locos nosse debemus; sic enim appellatae ab Aristotele sunt eae quasis sedes, e quibus argumenta promuntur. Itaque licet definire locum esse argumenti sedem, argumentum autem, rationem quae rei dubiae faciat fidem»;

8 Looking at the diagram 4 in the Appendix, the intrinsic topics are sixteen: (1) from the whole (a toto), (2) from the parts of the whole (a partibus), (3) from a sign (a nota), (4) from conjugates (a coniugata), (5) from genus (a genere), (6) from a form (a forma), (7) from a similarity (a similitudine), (8) from a difference (a differentia), (9) from a contrary (a contrario), (10) from conjoined things (ab adiunctis), (11) from antecedents (ab antecedentibus), (12) from consequences (a consequentibus), (13) from incompatibles (a repugnantibus), (14) from causes (a causis), (15) from effects (ab effectis), (16) from comparison of greater or lesser or equal things (a comparatione maiorum, vel minorum vel parium).

9 Looking at the diagram 4 in the Appendix, the extrinsic topics are entirely based upon testimony (testimonium), which is defined as everything which is brought in from some outside area to create belief. The authority of testimony is conferred either by nature (ex naturae auctoritate) or by time (ex temporis auctoritate). See Cicero, Topica, 73, p. 154, 10-11: «Testimonium autem nunc dicimus omne quod ab aliqua re externa sumitur ad faciendam fidem». See also Aristotelis Opera, ed. I. Bekker, Academica Regia Borussica, editio altera quam curavit O. Gigon, 5 vols., Berolini 1960-1961 ( $1^{\mathrm{a}}$ ed. 1830-1870), A $21355 \mathrm{~b}^{35} \mathrm{ff}$. and A 15, 1375a $\mathrm{a}^{22} \mathrm{ff}$.

10 The De inventione and the Topica enjoyed a wide distribution during the Early Middle Ages; the first text, especially, has been the most important source for rhetoric until the twelfth century. On the contrary, neither the De oratore nor the Partitiones oratoriae have been known by the authors of the Middle Ages. See De Filippis, R., Loquax pagina. La retorica nell'Occidente tardo-antico e alto-medievale, (Institutiones, 2), Roma, Città Nuova, 2013, pp. 29-48. 


\section{QUINTILIANUS'S LIST OF TOPICS}

As it is well known, the Topics were primarily employed in the fields of rhetoric and law, from Cicero's time up to the fifth century. The first rhetorical textbook-so far as we knowcomposed at the end of the first century A.D., is Quintilian's Institutiones oratoriae, in which we can find both of the lists of topics Cicero has put forth. ${ }^{11}$ In the fifth book, Quintilian introduces the topics by first proposing a twofold division probationes, into inartificiales and artificiales; this latter category is further divided into signa, exempla, and argumenta. Looking at diagram 5 in the Appendix, the arguments concern what we would now call, as it were, both the Ciceronian material and formal topics (i.e., most of the De inventione's attributes and all the Topica's loci). ${ }^{12}$ Although we can find a certain number of differences among the lists of Cicero and Quintilian, the resemblances are undoubtedly greater. In this regard, the most important thing to note here is that Quintilian's topical schema attests to a connection between both of Cicero's lists, so much so that we do not find any remark about a possible distinction between the different species of topics enumerated here. The decisive proof lies in the end of the chapter, where, after having commented upon every topic in detail, Quintilian briefly recapitulates the entire list in the following way:

And so, to sum up briefly: Arguments are derived from Persons; Motives; Places; Time (of which distinguished three phases, Antecedent, Contemporary, and Subsequent); Means (under which we included Instruments); Manner (that is, how something was done); Definition; Genus; Species, and Differentiae; Properties; Elimination; Division; Beginning, Development and Culmination; Similarities and Dissimilarities; Contradictions; Consequences; Causes and Effects; Outcomes; Conjugates; and Comparison, which is divided into a number of Species. ${ }^{13}$

The order in which the topics are presented here does not seem to suggest any particular ratio. However, we can register the fact that Quintilian first proposes most of Cicero's attributes of person and act, and then afterwards introduces the topics of the Topica, bringing together all these species into a single list.

Finally, it is interesting to stress that Quintilian's main purpose lies in pedagogical training; this is precisely why he describes, more than once, the necessary skills of an orator-he must find the appropriate topic for each kind of particular cause, rather than knowing perfectly the theory at hand along with its rules. It means that, theoretically speaking, it is possible to draw, from each topic, an infinite number of arguments which can be only discovered through constant practice.

11 See Quintilian, The Orator's education, ed. and transl. by Donald A. Russell, Cambridge, The Loeb Classical Library, 2001. See also Lehmann, P., «Die Institutio oratoria des Quintilianus im Mittelalter», in Philologus, 89 (1934), pp. 349-383; Winterbottom, M., «Quintilian», in L. D. Reynolds (ed.), Texts and Transmission. A Survey of the Latin Classics, Oxford, Oxford Clarendon Press, 1983, pp. 332-334; Murphy, J. J., «Quintilian's Influence on the Teaching of Speaking and Writing in the Middle Ages and Renaissance», in ID. (ed.), Latin Rhetoric and Education in the Middle Ages and Renaissance, Adelshot, Ashgate, 2005; De Filippis, R., Loquax pagina, o.c., pp. 44-46.

12 See Quintilian, The Orator's education, V, x.

13 Quintilian, The Orator's education, vol. II, 3-5, p. 415; ibid., V, x, 94, p. 414: «Ergo, ut breviter contraham summam, ducuntur argumenta a personis causis locis tempore (cuius tres partes diximus, praecedens, coniunctum, insequens), facultatibus (quibus instrumentum subiecimus), modo (id est, ut quidque sit factum), finitione, genere specie differentibus propriis, remotione, divisione, initio, incremento summa, similibus dissimilibus, pugnantibus, consequentibus, efficientibus, effectis, eventis, coniugatis, comparatione, quae in pluris diducitur species». 


\section{THE RHETORES LATINI MINORES: THE LISTS OF FORTUNATIANUS, JULIUS VICTOR, AND MARTIANUS CAPELLA}

After Quintilian, we must look at three of the rhetores latini minores of the fourth and fifth centuries, whose textbooks on rhetoric clearly recall Cicero's list of topics: Consultus Fortunatianus, Julius Victor, and Martianus Capella.

Although we know neither precisely where he was born, nor the chronology of his life, Fortunatianus is commonly considered the first among these authors. His Ars rhetorica is very close to Cicero's Partitiones oratoriae with respect to the literal form of question and answer; this is likely because it was confined to a school context. ${ }^{14}$ Looking at diagram 6 of the Appendix - and setting aside the first distinction of the genera argumentorun into artificiale and inartificiale - the novelty here lies is the fourfold division of topics and arguments on the basis of the time in which the cause at issue has been committed: ante rem, in re, circa rem, and post rem. Scholars do not agree on the sources of this new division, which could be derived from the Stoics, or perhaps from Ermagora; or, perhaps even from a disciple of Ermagora named Aquilio. ${ }^{15}$ At any rate, among the topics, it is easy to acknowledge several of Cicero's topics understood as attributes as well as seats of arguments, although Fortunatianus has not given an explanation of any particular one.

Nevertheless, a similar fourfold division is also found in Julius Victor's Ars rhetorica (Appendix, Diagram 7); unlike Fortunatianus, he devotes a long section to explain every topic in detail, providing also an example for each of them, in view of their application to the different species of juridical causes called status. ${ }^{16}$

Finally, Martianus Capella, in the fifth book of the De Nuptiis Philologiae et Mercurii devoted entirely to rhetoric, rather oddly presents two different lists of topics: the first undoubtedly belongs to Cicero's Topica and was probably taken from Victorinus (Appendix, Diagram 8); the second, found at the end of the chapter, is clearly taken from Fortunatianus's Ars rhetorica (Appendix, Diagram 9). ${ }^{17}$ Martianus does not specify why he offers two lists, and moreover seems to be completely unaware that both lists share many topics in common.

14 See Consultus Fortunatianus, Ars rhetorica, intr., ed. crit., trad. it. e commento a c. di L. Calboli Montefusco, Bologna, Patron, 1979; Calboli Montefusco, L., «Introduzione», in Consultus Fortunatianus, Ars rhetorica, o.p., pp. 1-60; id., «Il nome di Chirio Consulto Fortunaziano», in Hermes, 107 (1979), pp. 78-91; Carruthers, M., Late Antique Rhetoric, Early Monasticism, and the Revival of School Rhetoric, in C. D. Lanham (ed.), Latin Grammar and Rhetoric. From Classical Theory to Medieval Practice, London - New York, Continuum, 2002, pp. 239-257.

15 See Calboli Montefusco, L., «Commento», in Consultus Fortunatianus, Ars rhetorica, o. p., pp. $395-396$.

16 See C. Iulii Victoris Ars rhetorica, R. Giomini - M.S. Celentano (eds.), (Bibliotheca scriptorum graecorum et romanorum Teubneriana), Leipzig, B. G. Teubner, 1980. On Julis Victor see: Leff, M. C., The Material of the Art in the Latin Handbooks of the Fourth Century a.D., in B. Vickers (ed.), Rhetoric Revalued: Papers from the International Society for the History of Rhetoric, Binghamton, Center for Medieval \& early Renaissance studies, 1982, pp. 71-78; Celentano, M. S. «La codificazione retorica della comunicazione epistolare nell'Ars Rhetorica di Giulio Vittore», in Rivista di filologia e di istruzione classica, 122 (1994), pp. 422-435; Ead., «Un galateo della conversazione nell'Ars Rhetorica di Giulio Vittore», in Vichiana, III S., 1 (1990), pp. 245-253; Ead., «Le regole della comunicazione: pragmatica e antichi manuali di retorica», in P. Radici Colace - A. Zumbo (eds.), Letteratura scientifica e tecnica greca e latina, Atti del seminario internazionale di studi (Messina, 29-31 ottobre 1997), Messina , EDAS, 2000, pp. 263-274.

17 See Martianus Capella, De nuptiis Philologiae et Mercurii, J. Willis (ed.), Leipzig, B. G. Teubner, 1983, V, 474-501; ibid., 557-560. See also Hinks, D., Martianus Capella on Rhetoric, Diss., Cambridge, Trinity College Cambridge, 1935; Fischer, H., Untersuchung über die Quellen der Rhetorik des Martianus Capella, Diss., Breslau, Hermann Eschenhagen K. G., 1936; Leff, M. C., «St. Augustine and Martianus Capella: Continuity and Change in the Fifth-Century Latin Rhetorical Theory», in Communication quarterly, 24 (1976), pp. 2-9; Bennett 


\section{THE RHETORICAL AND DIALECTICAL APPROACH TO THE TOPICS: MARIUS VICTORINUS'S AND BOETHIUS'S LISTS OF TOPICS}

Between the fourth and eleventh centuries, it is possible to discern the coexistence of two different approaches on Cicero's topics of the Topica; both approaches will have a great influence in the early Middle Ages. Although they stem from a commentary devoted to Cicero's Topica, they have given rise to a different interpretation of the topics with respect to their possible field of application. The first approach has come from Marius Victorinus (around 280-365); although his commentary on Cicero's Topica is now lost, it is possible to state-on the basis of authors who have received and transmitted his theory (e.g., Martianus and Cassiodorus) - that Victorinus placed emphasis on the rhetorical nature of the loci, in view of their application mainly in the field of rhetoric. ${ }^{18}$ The second approach originates from Boethius (around 480524), who, besides commenting upon Cicero's Topica, also translated and provided commentary on Aristotle's Topica, and finally composed a monograph entitled De topicis differentiis; the latter was a large-scale project aimed at, among other things, contesting Victorinus's interpretation, in order to restore, on the basis of his Greek sources, the dialectical value of the loci. ${ }^{19}$ The main difference between the two approaches lies in the way in which the topics work in order to produce belief in something which is in doubt: in line with the Cicero-Victorinian transmission, topics do not require an analysis of the proposition from a logical point of view; on the contrary, following the line of Cicero-Boethian transmission, they are closely connected to the theory of predicable, and are of two species: the maximal propositions (maximae propositiones) and the differences of maximal propositions (differentiae maximarum propositionum), with which it is possible to divide and classify the same maximal propositions. ${ }^{20}$

B. S., «The Rhetoric of Martianus Capella and Anselm de Besate in the Tradition of Menippean Satire», in Philosophy andRrhetoric, 24 (1991), pp. 128-142; Ramelli, I., «Introduzione», in Marziano Capella, Le nozze di Filologia e Mercurio, I. Ramelli (ed.), Milano, Bompiani, 2001, pp. VII-CIV.

18 See Hadot, P., Marius Victorinus: recherches sur sa vie et ses oeuvres, Paris, Etudes Augustiniennes, 1971. Victorinus also composed a commentary to Cicero's De inventione. See Marius Victorinus, Explanationes in Ciceronis Rhetoricam, C. Ippolito (ed.), Turnhout, Brepols, 2006. See also A. Van de Veyer, «Les Etapes du développement Philosophique du Haut Moyen Age», in Revue Belge de Philologie et d'Histoire, 8 (1929), pp. 425-452;

19 See Anicius Manlius Severinus Boethius, In Topica Ciceronis Commentariorum libri sex, in PL 64, coll. 1039-1174; ID., De Topicis differentiis und die byzantinische Rezeption dieses Werkes, Einleitung und textkritische Ausgabe von D. Z. Nikitas, (Corpus Philosophorum Medii Aevi-Philosophi Byzantini, 5), Athens-Paris-Bruxelles, The Academic of Athens-J. Vrin-Editions Ousia, 1990; Boethius's De topicis differentiis, translated, with notes and essays on the text by E. Stump, Ithaca - London, Cornell University Press, 1978; ID., Topica. Translatio Boethii, Fragmentum Recensionis Alterius et Translatio Anonyma, L. Minio-Paluello (ed.), (Aristoteles Latinus, V. 1-3), Bruges 1969. See also Magnano, F., Il De topicis differentiis di Severino Boezio, (Machina philosophorum, 41), Palermo, Officina di Studi Medievali, 2014; Ead., Boezio e l'assiomatizzazione dei loci ciceroniani, in Schola Salernitana. Annales, 15 (2011), pp. 67-99; Ebbesen, S., Commentators and Commentaries on Aristotle's Sophistici Elenchi: a Study of Post-Aristotelian Ancient and Medieval Writings on Fallacies, Leiden, Brill, 1981; id., «The Theory of Loci in Antiquity and the Middle Ages», in K. Jacobi (ed.), Argumentationstheorie: Scholastische Forschungen zu den logischen und semantischen Regeln korrekten Folgerns, Leiden-New York-Cologne, Brill, 1993, pp. 14-39; id., La logica scolastica dell'antichità come fonte della logica scolastica medievale, in La Logica nel Medioevo, presentazione di A. K. Rogalski, trad. it. a cura di P. Fiorini, Milano, Jaca Book, 1999, pp. 1-32 ; Stump, E., «Boethius's Works on the Topics», in Vivarium, 12 (1974), pp. 77-93; Ead., «Boethius's Theory of Topics and Its Place in Early Scholastic Logic», in L. Obertello (ed.), Atti del Congresso Internazionale di Studi Boeziani (Pavia, 5 -8 ottobre 1981), Roma, Herder, 1981, pp. 249-262; Ead., «Topics: Their Development and Absorption into the Consequences», in N. Kretzmann-A. Kenny-J. Pinborg (eds.), The Cambridge History of Later Medieval Philosophy, Cambridge, Cambridge University Press, 1988, pp. 315-334.

20 See Boethius, De topicis differentiis, II, III, 1-2, 1185A, p. 25, 8-11.: «Locus namque est, ut M. Tullio placet, argumenti sedes. Cuius definitionis quae sit vis paucis absolvam. Argumenti enim sedes partim maxima propositio intellegi potest, partim propositionis maximae differentia». 
Since Victorinus's commentary to Cicero's Topica is lost, let us now focus our attention on Boethius's De topicis differentiis. According to Boethius, the discipline of the topics is the foundational discipline for dialecticians, rhetoricians, and philosophers, precisely because it is the only way to discover the starting points of all types of argumentation. ${ }^{21}$ In his last logical writing, Boethius arrives at this view by comparing, in a particularly ingenious and original way, the division of topics handed down by Themistius and Cicero (i.e., the Greek and the Latin traditions on the topics). In the second book, he first introduces Themistius's two categories of topics (Appendix, Diagram 10) - the maximal propositions and the differences of maximal propositions, respectively; in the third book, however, he presents Cicero's list of topics of the Topica (Appendix, Diagram 11). Both the lists are meant as a list of dialectical topics; indeed, Boethius's aim is to show, first, in which way each division differs from the other, second, in which way each matches the other, and third, in which way each list can in turn contain the other (Appendix, Diagrams 12-13). ${ }^{22}$ In order to achieve this aim, Boethius transformed the meaning of Cicero's topic of the Topica through a procedure which is considered to be a sort of 'axiomatisation' through three significant steps: in his commentary, he interprets Cicero's topics in the Topica as Themistius's differences of maximal propositions; afterwards, he punctually assigns, in the same commentary, a maximal proposition to each Cicero's topic; finally, he placed emphasis, in the third book of the De topicis differentiis, upon the original axiomatic nature of Ciceronian topics, in order to bring out their dialectical value - a process brought to completion in this text alone, as they are here presented as dialectical topics in all respects. ${ }^{23}$

However, Boethius also submitted Cicero's topics of the De inventione to the same process of 'axiomatization' - these latter topics now clearly understood as rhetorical topics. Moreover, by eluding clearly to Cicero's original intentions, Boethius comes to demonstrate-and not without originality - the way in which the rhetorical topics can be drawn from dialectical topics, by showing a fourfold possible derivation: two species from Themistius's list (Appendix, Diagrams 14-15) and two species from Cicero's list (Appendix, Diagrams 16-17), respectively.

By looking at the diagrams in the Appendix, it is easy to see that dialectic and rhetoric are now put into a relation of genus and species, or of universal and particular, therefore enshrining the definitive subordination of rhetoric to dialectic. In this way Boethius has theoretically founded the direction towards which rhetoric must now look, together with dialectic, in order to realize itself and achieve its goal: the search for Truth. ${ }^{24}$

21 See ibid., I, vII, 16-20, 1181D-1182A, pp. 18, 8-19, 4.

22 See ibid., I, I, 2-3, 1173BC, pp. 1, 8-2, 7: «Nunc vero consilium est aperire qui sint loci, quae horum differentiae, qui etiam quibus apti sint syllogismis. Nec id simpliciter atque uniformiter videtur esse faciendum, verum duplex est tradenda partitio, una quidem ex Graecis voluminibus eruta, altera vero ex M. Tullii Topicis sumpta. Atque in his illud ad perfectionem speculationis est astruendum, ut quibus utraque divisio differat quibusque conveniat explicetur quoque modo altera alteram vicissim possit includere».

23 See Hasnawi, A., «Boèce, Averroès et Abû al-Barakât al-Baghdâdî, témoins des écrits de Thémistius sur les Topiques d'Aristote», in Arabic Sciences and Philosophy, 17 (2007), pp. 203-265; ID., «Topic and Analysis: The Arabic Tradition», in R. W. Sharples (ed.), Whose Aristotle? Whose Aristotelianism?, Aldershot, Ashgate, 2001, pp. 28-62; ID., «Taxinomie topique: la classification thémistéenne des lieux chez Boèce, Averroès et Abû al-Barakât al-Baghdâdî», in R. Arnzen-J. Thielmann (eds.), Words, Texts and Concepts Cruising the Mediterranean Sea, Leuven, Peeters, 2004, pp. 245-258; Magnano, F., «Boethius: the Division of Logic between Greek and Latin Traditions», in J. Brumberg (ed.), Ad notitiam ignoti. L'Organon dans la translatio studiorum à l'époque d'Albert le Grand, (Studia Artistarum, 37), Turnhout, Brepols, 2013, pp. 141-171.

24 See Green-Pedersen, N. J., The Tradition of the Topics in the Middle Ages. The Commentaries on Aristotle's and Boethius's 'Topics', München-Wien, Philosophia, 1984; Gersh, S., «Dialectical and Rhetorical Space. 


\section{CASSIODORUS'S LIST}

Immediately after Boethius's death, his logical and rhetorical works were gathered into a single codex in Constantinople between 522 and 526; these works did not make their way back into the West until the late tenth century. ${ }^{25}$ Accordingly, between the sixth and the ninth centuries, Victorinus's approach on the topics seems to have prevailed in those authors who had not direct knowledge of Boethius's De topicis differentiis. Nevertheless, Victorinus's and Boethius's theory of the topics seem to have converged into a single transmission through Cassiodorus, who probably knew both interpretations. In the second book of his Institutiones, he attributes to rhetoric the typical place of dialectic; he then, in the section devoted to rhetoric, passes over in silence precisely the rhetorical topics of Cicero's De inventione; lastly, he places Cicero's list of topics of the Topica among the instruments of dialectic (Appendix, Diagram 18): all these choices clearly reveal a Boethian influence. ${ }^{26}$ At any rate, Cassiodorus never speaks about topics intended as maximal propositions or their differences-according to Boethius's terminology. On the contrary, with regard to the list of topics and their examples, according to Pierre Hadot, Cassiodorus's principal sources were Victorinus's commentary on Cicero's Topica. Moreover, Cassiodorus was also the first to have used the ars topica as an exegetical method to explore the sense of Sacred Scripture; in fact, by annotating thirteen different symbols in the margins of his Expositio Psalmorum, Cassiodorus explicitly indicates to the monk of the monastery of Vivarium the various etymologies, definitions, syllogisms, topics, etc., employed by the Psalmist in his sacred argumentation. As is well known, this very peculiar choice of Cassiodorus aimed at arguing for the biblical origin of the liberal arts; in this way, he brings to completion the process begun by Augustine-i.e., the re-foundation of classical learning in the function of Christian knowledge. ${ }^{27}$

The great appreciation that Cassiodorus gives to the Topics is clearly stated at the end of his commentary to the Psalm 144:

If a careful student finds any themes additional to those mentioned, whether in the remaining psalms or in previous ones, which are to be applied to the Lord's praises, he should not doubt (this at least is my opinion) that they have a bearing on one or other of the modes which we have listed. He should not indict us with total failure to embrace clearly what we proclaim to be immeasurable. In my view the astute Aristotle sought to

The Boethian Theory of Topics and its Influence during the Early Middle Ages», in J. A. Aertsen-A. Speer (eds.), Raum und Raumvorstellungen im Mittelalter, Berlin-New York, De Gruyter, 1997, pp. 391-401;

25 See Obertello, L., Severino Boezio, 2 vols., I, (Collana di Monografie, 1), Genova, Accademia Ligure di Scienze e Lettere, 1974; De Rijk, L. M, «On the Chronology of Boethius’ Work on Logic», in Vivarium, 2 (1964), pp. 1-49 and 125-162.

26 See Cassiodorus Senator, Institutiones, R.A.B. Mynors (ed.), Oxford, Oxford Clarendon Press, 1937, in PL 70, coll. 1149-1220, II, II, 15-17. See also d'Onofrio, G. «Topica e sapere teologico nell'alto medioevo», in J. Biard-F. M. Zini (eds.), Les lieux de l'argumentation. Histoire du syllogisme topique d'Aristote à Leibniz, (Studia Artistarum, 22), Turnhout, Brepols, 2009, pp. 141-170.

27 See Cesera-Gastaldo, A., «Contenuto e metodo dell'Expositio Psalmorum di Cassiodoro», in Vetera Christianorum, 5 (1968), 61-71; Schlieben, R. Cassiodors Psalmenexegese, Dissertation, Tubingen 1970; Hahner, U., Cassiodors Psalmenkommentar: Sprachliche Untersuchungen, München, Arbeo-Gesellschaft, 1973; O’ Donnell, J. J., Cassiodorus, Berkeley-Los Angeles-London, University of California Press, 1979; Pavan, M., «I valori della tradizione classica nell'insegnamento del Vivarium», in S. Leanza (ed.), Flavio Magno Aurelio Cassiodoro. Atti della settimana di studi, Soveria Mannelli, 1986; Simonetti, M., «L'Expositio Psalmorum di Cassiodoro», in Cassiodorus, 4 (1998), 125-139; Magnano, F., «La teologia 'topica' dell'Expositio Psalmorum di Cassiodoro», in XLI Incontro di studiosi dell'Antichità Cristiana: La teologia dal V all'VIII secolo fra sviluppo e crisi, (Studia Ephemeridis Augustinianum, 140), Roma, Istitutum Patristicum Augustinianum, 2014, pp. 361-393. 
match this when he assembled the topics for secular arguments with remarkable subtlety; in this way just as all discourse could be enclosed by letters, so by that combination all cultivated learning could be embraced by published judgment. From this source the dialecticians compressed their discussions in abbreviated syllogisms; from it the orators rushed along the rivers; from it poets surround themselves with beautiful blossoms; from it satirists, historians, comic and tragic poets, were enriched, so that anything set apart from this combination seems virtually to lie beyond the tongue of man. Aristotle bestowed the title Topics on this collection. Topics are the basis of arguments, by which the purpose of the disputant to elicit belief is achieved as though of first principles. No religious scruples condemns our reading and discussing this work, for whatever is not found to be hostile to sacred literature is investigated without harm. ${ }^{28}$

From this we can gather that, in Cassiodorus's philosophical and theological production, the adaptation of the topics to the novel necessities of Christianity can be considered as already fully completed.

\section{ISIDORUS'S LIST OF TOPICS}

In the sixth and seventh centuries two interpolated versions of Cassiodorus's Institutiones, which both include excerpts from the De topicis differentiis, will circulate in the West; however, Isidorus (around 560-636), bishop of Seville, is the author who, most of all, guaranteed the transmission of the list of topics to the Carolingian Ages. ${ }^{29}$ In his encyclopaedic text, composed of twenty books and entitled Etymologiae sive origines, he clearly follows Cassiodorus, especially with regard to the section devoted to the topics. In the second book, he presents rhetoric and dialectic in a single section, where the list of topics is placed in chapter 30 (Appendix, Diagram 19), as instruments of dialectic. ${ }^{30}$ Like Cassiodorus, Isidorus also divides topics into intrinsic and extrinsic topics, by enumerating the topics belonging to each of these two categories and by providing an example for each of them, taken from a rhetorical context. Hence, as regards Isidorus's list of topics, it can be stated that we do not find any substantial change.

28 Cassiodorus, Explanation of the Psalms, translated and annotated by P. G. Walsh, 3 voll., (Ancient Christian Writers, 53), New York, Paulist, 1991,3, pp. 430-431; Cassiodorus Senator, Expositio Psalmorum, M. Adriaen (ed.), 2 vols., (Corpus Christianorum Series Latina, 97), Turnhout, Brepols, 1958, II, p. 1297, 327-346: «Si quam vero partem supra ista quae diximus, sive in futuris, sive in praeteritis psalmis diligens perscrutator invenerit, quae ad laudes Domini debeat applicari, ad supradictorum aliquem modum (ut tamen nos opinamur) non dubitet pertinere; nec accuset a nobis ad liquidum minime comprehensum, quod profitemur immensum. Hoc Aristoteles acer ingenio (ut arbitror) aemulatus, argumentorum saecularium loca mirabili subtilitate collegit; ut sicut universus sermo litteris, ita et illa complexione omnis humanitas prolata sententia clauderetur. Hinc dialectici disputationes suas compendiosis collectionibus arctaverunt; hinc oratores velut quaedam flumina cucurrerunt, hinc poetae decoris floribus ambiuntur; hinc satyrici, hinc historici, hinc comici tragicique ditati sunt, ut pene ab humana lingua videatur exceptum, quod ab hac fuerit complexione divisum. Huic rei topica nomen imposuit. Topica vero sunt argumentorum sedes, ex quibus ad faciendam fidem velut elementis quibusdam conficitur intentio disserentis. Quod legere atque tractare religio nulla condemnat, quoniam innoxie requiritur, quidquid sacris litteris non probatur adversum».

29 See Brehaut, E., An encyclopedist of the Dark Ages: Isidore of Seville, (Columbia University Studies in History, Economics, and Public Law, 48), New York, Burt Franklin, 1912; Fontaine, J., Isidore de Séville et la culture classique dans l'Espagne visigotique, 2 voll., Paris, Études Augustiniennes, 1959; Reydellet, M., «La diffusion des Origines d'Isidore de Séville au haut Moyen Age», in École Française de Rome, Mélanges d'archéologie et d'histoire, 78 (1966), pp. 383-437.

30 See Isidorus Hispalensis, Etymologiarum sive Originum libri XX, W. M. Lindsay (ed.), Oxford, E typographeo Clarendoniano, 1911, in PL 82, coll. 140-150, II, Xxx, 1-18. 


\section{ALCUIN OF YORK'S LIST OF TOPICS}

The eighth and ninth centuries are those of the Carolingian period, whose protagonists receive as an inheritance a patrimony of knowledge, which with respect to the liberal arts was already consolidated by the synthesis of available encyclopaedias. Indeed, the liberal arts, together with Sacred Scripture and the exegesis of the Fathers, are now understood as the main pillars on which to cement the identity of the new Christian kingdom established by Charlemagne. The master of the Schola Palatina, Alcuin of York (around 730-804), is certainly the most important promoter of Charlemagne's political and religious designs. Basing himself on Augustine's conception on the natural origin of the liberal arts, Alcuin continues to walk on the fertile ground traced by the intellectuals of the Roman-barbarian kingdoms, by definitively incorporating the liberal arts as instruments of ascent in the gradual process of reunification with God, instruments between which dialectic certainly plays a role of prominence. In his textbook entitled De dialectica, Alcuin presents the list of topics in Chapter 15 (Appendix, Diagram 20), and his sources are Cassiodorus's Institutiones and Isidorus's Etymologiae ${ }^{31}$ however, it is surprising to find here, as well as in Chapters 12 through 14, a very large number of extracts from the second book of the De topicis differentiis, some of which can be linked neither to the two intermediary versions of Cassidorous's Institutiones, nor to Isidorus's Etymologiae. Some authoritative scholars, such as Manitius, have in fact suggested that Alcuin would directly employ Boethius's De topicis differentiis; this is an interesting hypothesis which, although so far ignored by historians of logic, still remains undecided in the absence of a critical edition of the text. ${ }^{32}$

There are numerous textual debts in Alcuin, sources such as Augustine, Boethius, Cassiodorus and Isidore, or the Categoriae decem; such sources are often literally transcribed, especially as regards the fifteenth chapter devoted to the topics. Despite these textual debts, it is possible to take note of more than one novelty. First of all, the interlocutory character of the treatise suggests us that it may be considered as a continuation of the fictitious dialogue between Alcuin and Charlemagne begun in the treatise entitled De rhetorica et virtutibus. ${ }^{33}$ Thus, this particular aspect may prompt us to consider these two texts as unique. Furthermore, although the list of sixteen topics is that of Cicero's Topica, the intrinsic topics are here called loci qui ipso negotio de quo agitur, where the term negotium clearly recalls the rhetorical context and is linked to the same way in which Martianus Capella

31 See Alcuinus Eboracensis [=Alcuinus], De Dialectica, PL 101, [coll. 949-976B], 968A-972D. See also Luscombe, D. E., «Dialectic and Rhetoric in the Ninth and Twelfth Centuries: Continuity and Change», in J. Fried (ed.), Dialektik und Rhetorik im früheren und hohen Mittelalter. Rezeption, Überlieferung und gesellschaftliche Wirkung antiker Gelehrsamkeit vornehmlich im 9. und 12. Jahrhundert, (Schriften des historischen Kollegs. Kolloquien, 27), München, Oldenbourg, 1997 pp. 1-20.

32 See Manitius, M., Geschichte der lateinischen Literatur des Mittelalters, 3 vols, Munich, W. Fink, 19111931 (repr. 1965-1973), I, Von Justinian bis zur Mitte des zehnten Jahrhunderts, p. 283. See also Wallach, L., Alcuin and Charlemagne: Studies in Carolingian History and Literature, Ithaca-New York, Cornell University Press, 1959; id., Diplomatic Studies in Latin and Greek Documents from the Carolingian Age, Ithaca, Cornell University Press, 1977; Marenbon, J., From the Circle of Alcuin to the School of Auxerre: Logic, Theology and Philosophy in the Early Middle Ages, Cambridge, Cambridge University Press, 1981; Nash-Marshall, S., «Boethius's Influence on Theology and Metaphysics to c. 1500», in N. H. Kaylor Jr. P. E. Phillips (eds), A Companion to Boethius in the Middle Ages, Leiden-Boston, Brill, 2012, pp. 163-191.

33 See Alcuinus, De rhetorica, K. Halm (ed.), in Rhetores latini minores. Ex codicibus maximam partem primum adhibitis, 16, Disputatio de rhetorica et de virtutibus sapientissimi regis Karli et Albini magistri, Leipzig, B.G. Teubneri 1863, pp. 523-550, in PL 101, coll. 919-949; ID., The Rhetoric of Alcuin and Charlemagne, Traslation, with Introduction, Latin Text, and Notes by W. S. Howell, New York, Russel \& Russel, 1965. 
presented the Ciceronian topics in the fifth book of his De Nuptiis Philologiae et Mercurii entirely devoted to Rhetoric. ${ }^{34}$ Moreover, the most important novelty in the field of topics consists in the reappearance of two maximal propositions which clearly belong to the list of Themistius ${ }^{35}$. Again, some arguments are here explained, for the first time, by using biblical examples and finally, the extrinsic topics are only announced but never presented in detail.

The later generations of the Carolingian ages-i.e., those of Rabanus Maurus as well as the commentators of Martianus's De Nuptiis Philologiae et Mercurii-will proceed in the same territory already traced by Alcuin, although the more advanced developments with respect to the employment of topics in the fields of theology and philosophy must be found, no doubt, in John Scotus Eriugena's scientific production. ${ }^{36}$

\section{AN ANONYMOUS LIST OF TOPICS}

As has already been indicated, the tenth century - and to a greater extent the eleventh century - marked a revival of interest in dialectic, and in particular in the De topicis differentiis. This latter work in particular makes its reappearance in the West; in fact, the first commentaries on Boethius's logical work date back precisely to this period, although they today remain unedited. ${ }^{37}$

According to Green Pedersen, there are in this period two anonymous textbooks besides the commentaries, which pay specific attention to the topics and are both connected with the intense cultural life of the monastery of St. Gall: the first is entitled Dialectica, and it transmits a list of topics that clearly reproduces Cicero's list; the second text is entitled De syllogis-

34 See Alcuinus, De Dialectica, PL 101, 968AB: «C. In quot species dividuntur topicorum argumentationes?---A. Topicorum, id est, localium argumentatio triplex est, quia sunt argumenta, aut in ipso negotio, de quo agitur; aut ex rebus aliis tracta nascuntur; aut certe extrinsecus assumuntur».

35 See ibid., PL 101, 968C: «Hic necesse est intelligi, id parti congruere, quod toti convenit»; ibid.: «et necesse est eam rem bonam esse, cuius finis bonus est»; Boethius, De topicis differentiis, II, vII, 8, 1188C, p. 32, 20: «Quod toti convenit, id conveniat etiam parti»; ibid.: II, VII, 25, 1189D, p. 35, 20-21: «Cuius finis bonus est, ipsum quoque bonum est».

36 See Hrabani Mauri De institutione clericorum libri tres, D. Zimpel (ed.), (Freiburger Beiträge zur mittelalterlichen Geschichte. Studien und Texte herausgegeben von Hubert Mordek, 7), Frankfurt a.M., P. Lang, 1996; Remigius Antissiodorensis, Commentum in Martianum Capellam, C. E. Lutz (ed.), Leiden, Brill, 1965; Iohannis Scotti Annotationes in Marcianum, Lutz (ed.), Cambridge, The Mediaeval Academy of America, 1939. See also Haase, F. A., «Rhetoric between Praise of the Emperor and Education. The Contributions of Alcuin of York and Rhabanus Maurus for the Early History of Rhetoric in Europe during the Renovatio of Charlemagne and the Manuscript Alcuinus ad regem», in Troianalexandrina, 5 (2005), pp. 98-124; On the ninth century Martianus Capella's commentators see: Laistner, M., «Martianus Capella and his ninth century commentators», in Bulletin of the John Rylands Library, 9 (1925), pp. 130-138; Leonardi, C., «I commenti altomedievali ai classici pagani da Severino Boezio a Remigio di Auxerre», in La cultura antica nell'Occidente latino, XXII Settimana di studi del Centro Italiano di Studi sull'Alto Medioevo (CISAM), 18-22 aprile 1974, Spoleto, presso la sede del Centro, 1975, pp. 459-504; ID., «Remigio di Auxerre e l'eredità della scuola carolingia», in I classici nel Medioevo e nell'Umanesimo. Miscellanea filologica, (Pubblicazioni dell'Istituto di Filologia classica e medievale dell'Università di Genova, 42), Tivoli, Istituto di filologia classica e medievale, 1975, pp. 271-288; Scoto Eriugena, Remigio di Auxerre, Bernardo Silvestre e Anonimi, I. Ramelli (ed.), Tutti i commenti a Marziano Capella, Milano 2006; On the use of topics by John Eriugena see: d'Onofrio, G., Fons scientiae. La dialettica nell'Occidente tardo-antico, (Nuovo Medioevo, 30) Napoli, Liguori, 1986, pp. 3-21.

37 The first manuscript of the De topicis differentiis, according to Lambertus De Rijk, dates back to the tenth century. See De Rijk, L. M., «On the Chronology of Boethius' Work on Logic», o.p.; Green-Pedersen, N. J., The Tradition of the Topics in the Middle Age, o.p., pp. 147-153. 
mis, and was probably written, according to De Rijk, by Notker Labeo (around 950-1022). ${ }^{38}$ Both texts transmit a very similar theory of the topics, although only the anonymous author of the Dialectica provides a clear list. Let us now turn our attention precisely to this text. According to Green Pedersen, its main sources are the compendia of Martianus Capella, Cassiodorus, and Isidorus, as well as Boethius's commentary on Porphyrius' Isagoge, his commentary on Cicero's Topica, as well as Victorinus's commentary on Cicero's Topica. Looking at Diagram 21 in the Appendix, the distinction between intrinsic and extrinsic topics is absent here, while the number of intrinsic topics has been already fixed by the tradition, i.e. sixteen. The anonymous author explains that from the topics ab antecedentibus, a consequentibus and a repugnantibus it is possible to extrapolate seven modes of hypothetical syllogisms, which always deal with true and necessary arguments, and are therefore useful primarily for the philosophers. ${ }^{39}$ Afterwards, the entire list of sixteen topics is in turn presented, and an example for each topic has been given; consequently, the other thirteen topics can only produce probable arguments, which is why-so our anonymous author explains - they are primarily useful for orators. Thus, the most important change in these centuries, with respect to the theory of topics, is the close connection which has been established between topics and hypothetical syllogisms: a theory which is also attested by the author of the De syllogismis.

Moreover, after the presentation of the list of dialectical topics (i.e., according to Cicero's classification), Anonymous also introduces the list of rhetorical topics found in Cicero's $D e$ inventione, i.e. the attributes of person and act, calling them quasi alia loci. This is another clear testimony of a tradition which, beginning with Cassiodorus, transmits the Boethian theory of bringing dialectic and rhetoric together into a single section, by clearly subordinating the list of rhetorical topics to the list of dialectical topics.

\section{GARLANDUS COMPOTISTA'S LIST OF TOPICS}

The logical production of Gerbert d'Aurillac (around 940-1003), unfortunately now lost, as well as the logical works of Abbo of Fleury (around 945-1004), ${ }^{40}$ definitely demonstrate that Boethius's theory on topics was slowly coming into use between the tenth and eleventh centuries. Nevertheless, the textbook which certainly marks a turning point, as regards the transmission of the list of topics, is Garlandus Compotista's Dialectica ${ }^{41}$ De Rijk, who was the first to publish its critical edition, places the date of the text's composition between 1040 and 1075; however, this date is not largely approved by all scholars, due to the fact that some

38 See Anomymus, Dialectica. Die Schriften Notkers und seiner Schule, P. Piper (ed.), Freiburg-Tübingen, J.C.B. Mohr, 1882, pp. LVI-LXxv; Notkerus Labeo, De syllogismis. Die Schriften Notkers und seiner Schule, P. Piper (ed.), Freiburg-Tübingen, J.C.B. Mohr, 1882, pp. 596-622. See Green-Pedersen, N. J., The Tradition of the Topics in the Middle Age, o.p., pp. 139-146.

39 Anonymous here seems to follow Cicero. See Cicero, Topica, 19-21, p. 124, 12; 53-57, pp. 142, 1-144, 19; See also Riposati, B., Studi sui Topica di Cicerone, Milano, Vita e Pensiero, 1947, pp. 116-129; Reinhardt, T., «Commentary», in Cicero, Topica, o.p., pp. 232-241 and 305-320; Obertello, L., «Introduzione», in Anicio manlio Severino Boezio, De hypotheticis syllogismis, testo critico, trad., intr. e commento di L. Obertello, Brescia, Paideia, 1969, pp. 15-196.

40 See Abbo floriacensis, Opera inedita I. Syllogismorum categoricorum et hypotheticorum enodatio, A. Van de Vyver (ed.), Bruges, De Temple, 1966 ; ID., De syllogismis hypotheticis, F. Schupp (ed.), (Studien und Texte zur Geistesgeschichte des Mittelalters, 56), Leiden-New York-Cologne, De Temple, 1997; id., Quaestiones grammaticales, A. Guerreau-Jalabert (ed.), Paris, Les Belles Lettres, 1982.

41 Garlandus Compotista, Dialectica, L. M. De Rijk (ed.), Assen, Van Gorcum, 1959. 
of them prefer to place its composition in the twelfth century. ${ }^{42}$ Garlandus never mentions his sources, nonetheless, in the fourth book, entirely devoted to the topics, he begins by presenting a brief summary of the first, and partially also of the second book, of Boethius's De topicis differentiis. He then proceeds to show the list of topics which are here understood as differences of maximal propositions and by giving for each of them the corresponding topic, now in turn understood as maximal proposition. Only at the end of this section, Garlandus specifies that all the topics can be divided into two categories, i.e. extrinsic and intrinsic (Appendix, Diagram 22), or even into three categories, i.e. extrinsic, intrinsic, and intermediate (Appendix, Diagram 23). As it is evident, Garlandus is following Boethius by presenting Cicero's as well as Themistius's divisions of topics. Despite the numerous resemblances, Eleonore Stump rightly stresses that Garlandus's Dialectica cannot be simply considered as a paraphrase of Boethius's De topicis differentiis, since the divergences are many and, in more than one case, they produce a different theory, which she has analysed in depth. ${ }^{43}$

The most important change is the one that we have already noted in Anonymous's Dialectica, i.e. the close connection of the topics with the hypothetical syllogisms; additionally, the topics are here understood as the principles from which the categorical syllogisms also arise. ${ }^{44}$ This is why Garlandus states that the study of topics is essentially propaedeutic to the study of syllogisms.

\section{CONCLUSION}

In the transmission of Cicero's lists of topics from antiquity to the early Middle Ages, we have observed two crucial changes: on the one hand, the migration of Cicero's list of the Topica from a rhetorical to a dialectical context; on the other hand, the slow but constant absorption of the topical doctrine into the new Christian sensibility. Nevertheless, Green Pedersen, in his attempt to reconstruct the tradition of the Topics in the Middle Ages, seems to have almost completely neglected the Late Antiquity and the Early Middle Ages, from the $6^{\text {th }}$ to the $11^{\text {th }}$ centuries, to be more specific, a very important period, thanks to which the topics have been transmitted to the Late Middle Ages. Although he mainly focused his attention on the commentaries of Aristotle's and Boethius's Topics, we have seen how these centuries have largely contributed to the subterranean but safe ferrying of the list of topics to the later ages. Indeed, in these centuries, in contrast to the previous rhetorical tradition, Cassiodorus decided to follow Boethius in placing, in the second book of the Institutiones, the list of topics among dialectical rather than rhetorical instruments. But Cassiodorus is also the first one who grafted the topics into the fruitful territory of the exegetical tradition; in fact, the topics, almost under-

42 See De Rijk, L. M., «Introduction», in Garlandus Compotista, Dialectica, o.p., pp. IX-LVIII; Green-Pedersen, N. J., The Tradition of the Topics in the Middle Age, o.p., pp. 155-159. Following Iwakuma, some scholars accept to postpone the date (1110-1120) and identify Garlandus with Garlandus of Besançon as the author. See Y. Iwakuma, «Vocales, or Early Nominalists», Traditio, 47 (1992), pp. 37-111; J. Marenbon, «Logic at the Turn of the twelfth century: a Synthesis», in I. Rosier-Catach (ed.), Arts du langage et théologie aux confins des XIe et XIIe siècles, Turnhout, Brepols, 2011, pp. 181-217.

43 Stump, E., «Dialectic in the Eleventh and Twelfth Centuries: Garlandus Composita», in History and Philosophy of Logic, 1 (1980), pp. 1-18; Ead., Dialectic and Its Place in the Development of Medieval Logic, Ithaca-London, Cornell University Press, 1989.

44 On the basis of Boethius's division of logic into invention (called pars inveniendi or topice) and judgment (called pars iudicandi or analytice), it seems that the topics are the principles from which all kinds of argumentation arise. See Magnano, F., «Boethius: the Division of Logic between Greek and Latin Traditions», o.p., p. 166. Thus Garlandus's theory of linking topics and syllogisms is clearly taken from Boethius. 
stood as places of the transcendence, are now able to disclose the divine revealed message. Therefore, it is not surprising that the fides, as new epistemological assumption, is now required in order to reveal the hidden meaning of sacred argumentation. Alcuin inherited this theory and adapted it to the new necessities of the Carolingian Empire. Therefore, in his theological and philosophical works, the topics are definitively put into service of the faith. Finally, the logical production belonging to the monastery of St. Gall testified the return of the $D e$ topicis differentiis in the West, where Garlandus's Dialectica signed the higher point of restoration of Boethius's theory on topics.

Thus, the two-faced character of Cicero's topics, Victorinian-rhetorical on the one hand, and Boethian-dialectical on the other, developed and transmitted in Late Antiquity, was not an obstacle to the transmission of the list of topics in the Early Middle Ages; on the contrary, it was finally corrected by Boethius, who subordinated the former to the latter. Hence, all these considerations enable us to conclude that the Early Middle Ages can be considered, from an epistemological point of view, as a long boethiana aetas. Although the corpus of Boethius's logical writings was not yet available, it seems, in fact, that the methodological approach of the Roman philosopher somehow continued to support the structure of the nascent theological system. 


\section{Cicero's Lists of Topics from Antiquity to the Early Middle Ages}

\section{APPENDIX}

\section{Diagram 1: Cicero, De inventione}

\begin{tabular}{|c|c|c|}
\hline \multicolumn{3}{|c|}{ ATTRIBUTA } \\
\hline \multirow{5}{*}{ ex negotii } & ex personis & $\begin{array}{r}\text { nomen } \\
\text { natura } \\
\text { victum } \\
\text { fortuna } \\
\text { habitus } \\
\text { affectio } \\
\text { studium } \\
\text { consilium } \\
\text { facta } \\
\text { casus } \\
\text { orationes }\end{array}$ \\
\hline & continentia cum ipso negotio & $\begin{array}{r}\text { brevis conplexio } \\
\text { causa } \\
\text { ante gesta rem } \\
\text { in ipso gerendo negotio quid actum sit } \\
\text { quid postea factum sit }\end{array}$ \\
\hline & in gestione negotii & $\begin{array}{c}\text { locus } \\
\text { tempus } \\
\text { modus } \\
\text { occasio } \\
\text { facultas }\end{array}$ \\
\hline & adiuncta negotio & $\begin{array}{r}\text { maius magnum } \\
\text { minus magnum } \\
\text { aeque magnum } \\
\text { simile } \\
\text { contrarium } \\
\text { disparatum } \\
\text { genus } \\
\text { pars } \\
\text { eventus }\end{array}$ \\
\hline & $\begin{array}{c}\text { quae negotio consequuntur } \\
\text { (consecutio) }\end{array}$ & $\begin{array}{r}\text { - quo id nomine appellari conveniat } \\
\text { - qui sunt principes et inventores, qui denique } \\
\text { auctoritatis eius et inventionis comprobatores } \\
\text { atque aemuli } \\
\text { - quae eius rei sit lex, consuetudo, pactio, } \\
\text { iudicium, scientia, artificium } \\
\text { - si natura eius evenire vulgo soleat an } \\
\text { insolenter et raro } \\
\text { - utrum homines id sua auctoritate compro- } \\
\text { bare an offendere in his consueverint }\end{array}$ \\
\hline
\end{tabular}




\section{Diagram 2: Cicero, De oratore}

\begin{tabular}{|c|c|c|c|}
\hline \multirow{3}{*}{ LOCI } & \multirow[b]{2}{*}{$\begin{array}{l}\text { ex sua sumi vi } \\
\text { atque natura }\end{array}$} & ex sua vi & $\begin{array}{r}\text { cum res quae sit tota quaeritur (definitio) } \\
\text { ut pars eius (partitio) } \\
\text { aut vocabulum }\end{array}$ \\
\hline & & $\begin{array}{c}\text { ab eo quod rem } \\
\text { attingat }\end{array}$ & $\begin{array}{r}\text { ex coniunctis } \\
\text { ex genere } \\
\text { ex parte quae est subiecta generi } \\
\text { ex similitudine } \\
\text { ex dissimilitudine } \\
\text { ex contrario } \\
\text { ex consequentibus } \\
\text { ex consentaneis } \\
\text { ex praecurrentibus } \\
\text { ex repugnantibus } \\
\text { ex causis } \\
\text { ex iis autem quae sunt orta de causis } \\
\text { ex maiore } \\
\text { ex minore } \\
\text { ex pari }\end{array}$ \\
\hline & $\begin{array}{l}\text { qui adsumuntur } \\
\text { foris }\end{array}$ & & $\begin{array}{r}\text { cum ea quae sunt foris neque haerent in rei } \\
\text { natura colliguntur }\end{array}$ \\
\hline
\end{tabular}

\section{Diagram 3: Cicero, Partitiones oratoriae}

\begin{tabular}{|c|c|c|c|c|}
\hline \multirow{4}{*}{ LOCI } & \multirow[b]{2}{*}{$\begin{array}{l}\text { quae in re } \\
\text { ipsa insitis }\end{array}$} & \multirow[b]{2}{*}{$\begin{array}{c}\text { ex eis rebus quae } \\
\text { quodammodo affectae } \\
\text { sunt ad id de quo } \\
\text { quaeritur }\end{array}$} & & $\begin{array}{r}\text { definitio } \\
\text { partium enumeratio } \\
\text { notatio verbis }\end{array}$ \\
\hline & & & & $\begin{array}{r}\text { coniugata } \\
\text { ex genere } \\
\text { exforma } \\
\text { ex similitudine } \\
\text { ex differentia } \\
\text { ex contrario } \\
\text { ex coniunctis } \\
\text { ex antecedentibus } \\
\text { ex consequentibus } \\
\text { ex repugnantibus } \\
\text { ex causis } \\
\text { ex effectis } \\
\text { ex comparatione maiorum } \\
\text { aut minorum } \\
\text { aut parium }\end{array}$ \\
\hline & \multirow{2}{*}{$\begin{array}{l}\text { quae sine } \\
\text { arte } \\
\text { putantur }\end{array}$} & \multirow{2}{*}{ testimonium } & divinum & $\begin{array}{r}\text { oracula } \\
\text { auspicia } \\
\text { vaticinationes } \\
\text { responsa sacerdotum } \\
\text { haruspicum } \\
\text { coniectorum }\end{array}$ \\
\hline & & & humanum & $\begin{array}{r}\text { ex auctoritate } \\
\text { ex voluntate } \\
\text { - ex oratione aut libera aut expressa: } \\
\text { in quo insunt scripta, pacta, promissa, } \\
\text { iurata, quaesita. }\end{array}$ \\
\hline
\end{tabular}




\section{Diagram 4: Cicero, Topica}

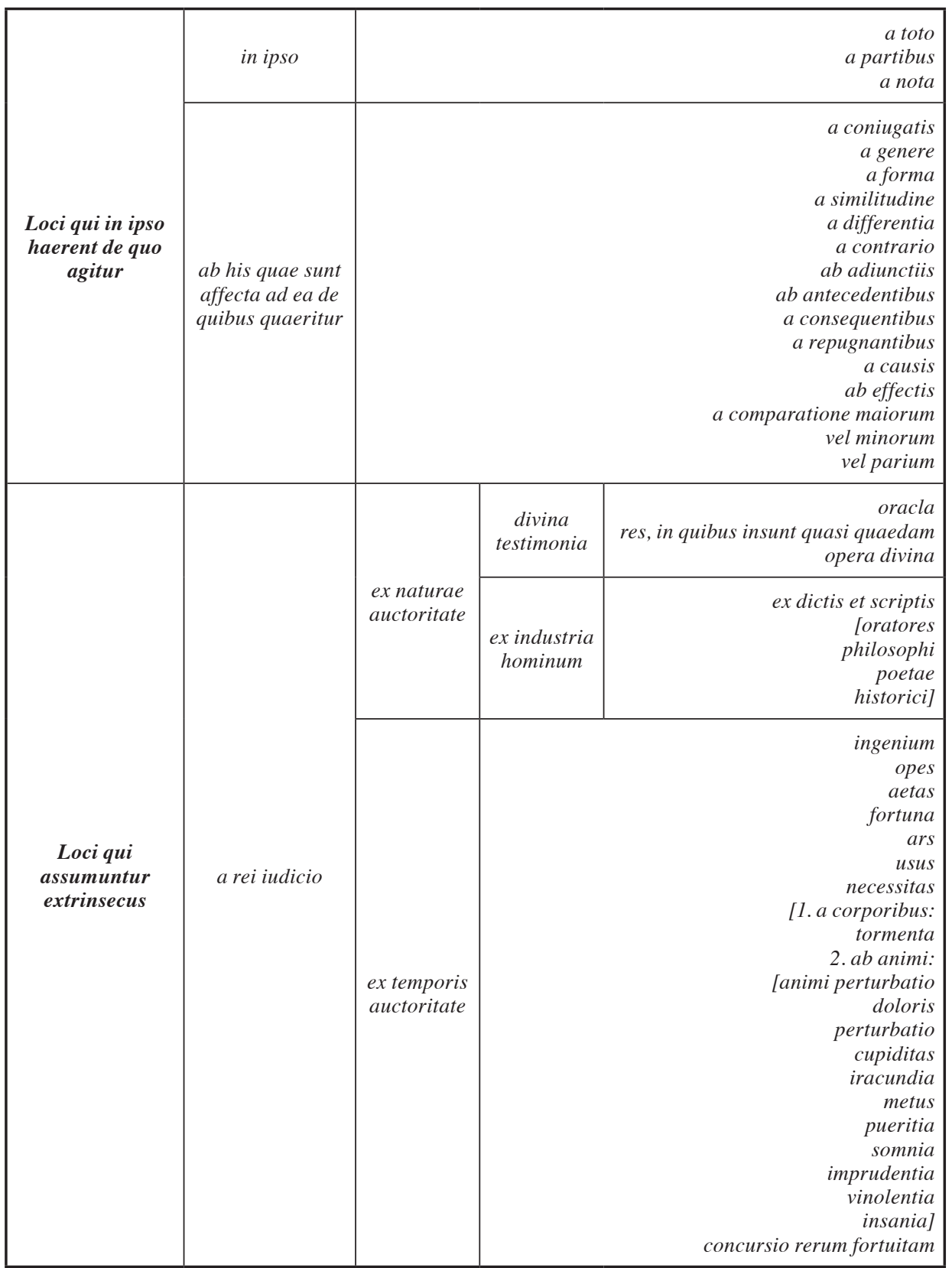


Diagram 5: QuintILIANus, Institutiones oratoriae

\begin{tabular}{|c|c|c|c|c|}
\hline & inartificiale & & & $\begin{array}{r}\text { praeiudicia } \\
\text { rumores } \\
\text { tormenta } \\
\text { tabulae } \\
\text { ius iurandum } \\
\text { testes }\end{array}$ \\
\hline & & signa & & $\begin{array}{r}\text { necessaria } \\
\text { non necessaria }\end{array}$ \\
\hline & & exempla & & $\begin{array}{r}\text { similia } \\
\text { dissimilia } \\
\text { contraria }\end{array}$ \\
\hline PROBATIONES & & & a personis & $\begin{array}{r}\text { genus } \\
\text { natio } \\
\text { patria } \\
\text { sexus } \\
\text { aetas } \\
\text { educatio et disciplina } \\
\text { habitus corporis } \\
\text { fortuna } \\
\text { condicio } \\
\text { animi natura } \\
\text { victus } \\
\text { studia } \\
\text { quid adfectet quisque } \\
\text { consilia praesentis et praeteriti et futuri } \\
\text { temporis } \\
\text { nomen }\end{array}$ \\
\hline & artificiales & argumenta & a re & $\begin{array}{r}\text { quare vel a causis } \\
\text { ubi vel a locis } \\
\text { quando vel a tempore (praecedens, coniunc- } \\
\text { tum, insequens) } \\
\text { quomodo vel a modo } \\
\text { per quae facta sunt vel a facultatibus }\end{array}$ \\
\hline & & & & $\begin{array}{r}\text { a finitione } \\
\text { a genere } \\
\text { a specie } \\
\text { a differentibus } \\
\text { a propris } \\
\text { a remotione } \\
\text { a divisione vel a partitione } \\
\text { ab incremento } \\
\text { a summa } \\
\text { a similibus } \\
\text { a dissimilibus } \\
\text { a pugnantibus } \\
\text { ab efficientibus } \\
\text { ex effectis } \\
\text { ab eventis } \\
\text { a consequentibus vel ab adiunct }\end{array}$ \\
\hline
\end{tabular}




\section{Diagram 6: Consultus Fortunantianus, Ars rhetorica}

\begin{tabular}{|c|c|c|c|}
\hline \multirow{6}{*}{ ARGUMENTA } & \multirow{5}{*}{ artificialia } & ante rem & $\begin{array}{r}\text { persona } \\
\text { res } \\
\text { causa } \\
\text { tempus } \\
\text { locus } \\
\text { modus } \\
\text { materia }\end{array}$ \\
\hline & & in re & $\begin{array}{r}\text { a toto } \\
\text { a parte } \\
\text { a genere } \\
\text { a specie } \\
\text { a differentia } \\
\text { a proprio } \\
\text { a definitione } \\
\text { a nomine } \\
\text { a multiplici appellatione } \\
\text { ab initio } \\
\text { a progressione vel profectu } \\
\text { a perfectione vel a consummatione }\end{array}$ \\
\hline & & circa rem & $\begin{array}{r}\text { a simili } \\
\text { [exemplum } \\
\text { similitudo } \\
\text { fabula } \\
\text { imago } \\
\text { exemplum verisimile] } \\
\text { a dissimili } \\
\text { a pari } \\
\text { a contrario } \\
\text { a maiore ad minus } \\
\text { a minore ad maius } \\
\text { a praecedenti } \\
\text { ab eo quod simul est vel a coniunctis } \\
\text { a consequentibus }\end{array}$ \\
\hline & & post rem & $\begin{array}{r}\text { ab eventu } \\
\text { a iudicato } \\
\text { [omnium hominum } \\
\text { aut plurimum } \\
\text { aut optiomorum } \\
\text { aut eminentium ex his } \\
\text { aut eorum qui in unaquaque arte vel scientia versari sunt] }\end{array}$ \\
\hline & & & $\begin{array}{r}\text { a coniugatione vel a coniugatis } \\
\text { a qualitate } \\
\text { a quantitate } \\
\text { a coniunctis } \\
\text { a partitione }\end{array}$ \\
\hline & inartificialia & & $\begin{array}{r}\text { in praeiudicia } \\
\text { in rumores } \\
\text { in tormenta } \\
\text { in tabulas } \\
\text { in ius iurandum } \\
\text { in testes }\end{array}$ \\
\hline
\end{tabular}


Diagram 7: Julius Victor, Ars rhetorica

\begin{tabular}{|c|c|c|c|}
\hline \multirow{5}{*}{ LOCI } & \multirow{4}{*}{ artificialia } & qui rem praecedunt & $\begin{array}{r}\text { a persona } \\
\text { [patria } \\
\text { nomen } \\
\text { genus } \\
\text { corporis habitudo } \\
\text { mores } \\
\text { vita } \\
\text { amici } \\
\text { aetas } \\
\text { in cessus } \\
\text { vultus] } \\
\text { a causa } \\
\text { a tempore } \\
\text { a loco } \\
\text { a materia } \\
\text { a modo sive ratione }\end{array}$ \\
\hline & & in re ipsa & $\begin{array}{r}\text { a toto } \\
\text { a parte } \\
\text { a genere } \\
\text { a specie } \\
\text { a differentia } \\
\text { a proprio } \\
\text { a definitione } \\
\text { a nomine }\end{array}$ \\
\hline & & circa rem & $\begin{array}{r}\text { a simili } \\
\text { a dissimili } \\
\text { a pari } \\
\text { a contrario } \\
\text { a maiore } \\
\text { a minore } \\
\text { a praecedente } \\
\text { ab eo quod simul est } \\
\text { a consequente }\end{array}$ \\
\hline & & post rem & $\begin{array}{l}\text { ab eventu } \\
\text { a iudicato }\end{array}$ \\
\hline & inartificialia & & $\begin{array}{r}\text { praeiudicia } \\
\text { rumores } \\
\text { tormenta } \\
\text { tabulae } \\
\text { ius iurandum } \\
\text { testes } \\
\text { divina testimonia } \\
\text { [responsa } \\
\text { omina } \\
\text { voces per vinum } \\
\text { vel per somnium } \\
\text { vel per dementiam } \\
\text { vel ab infantibus emissae ] }\end{array}$ \\
\hline
\end{tabular}




\section{Diagram 8: Martianus Capella, De Nuptiis Philologiae et Mercurii}

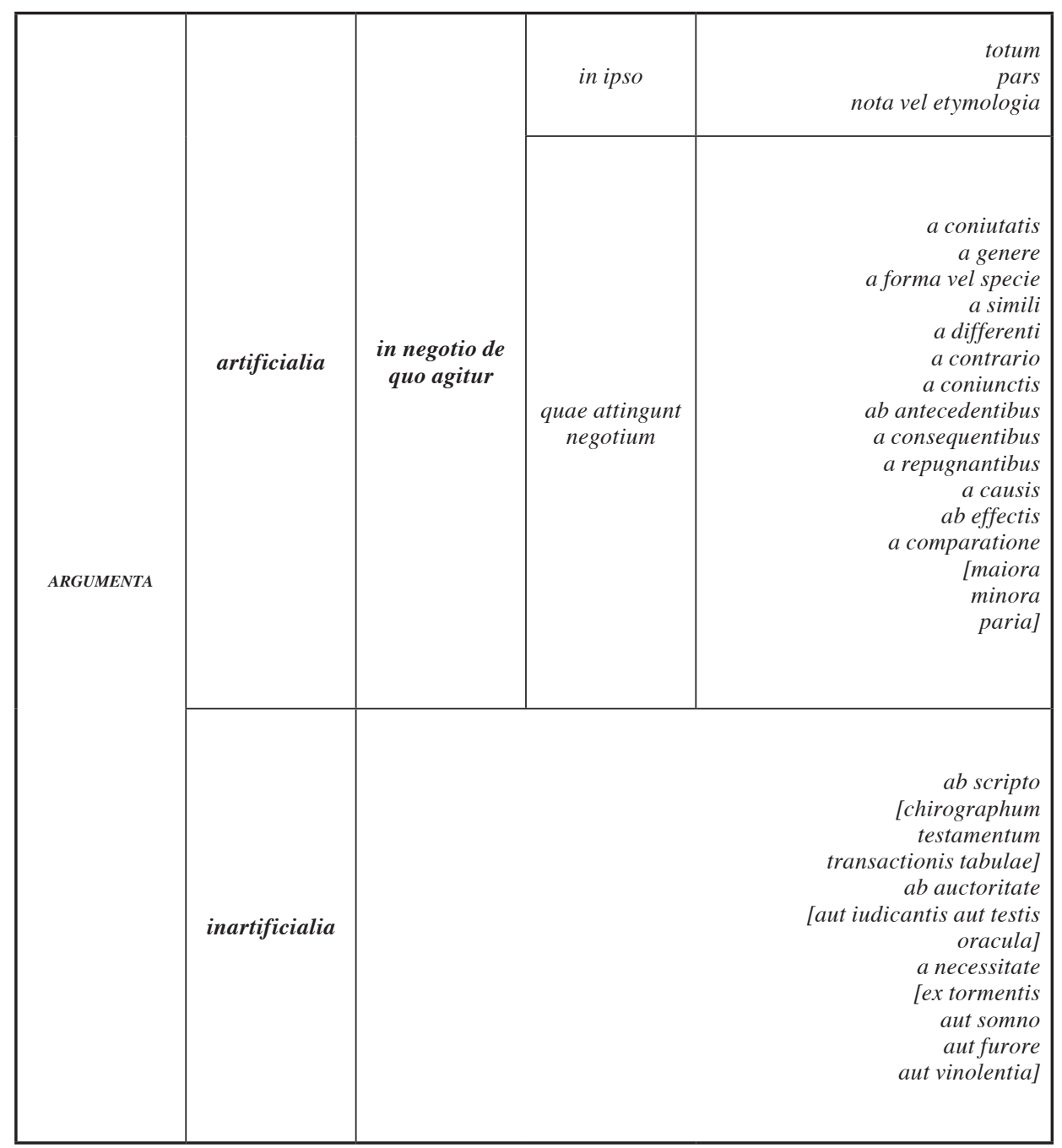




\section{Diagram 9: Martianus Capella, De Nuptiis Philologiae et Mercurii}

\begin{tabular}{|c|c|c|c|}
\hline \multirow{6}{*}{ ARGUMENTA } & \multirow{4}{*}{ artificialia } & ante rem & $\begin{array}{r}\text { a persona } \\
\text { a re } \\
\text { a causa } \\
\text { a tempore } \\
\text { a loco } \\
\text { a modo } \\
\text { a materia }\end{array}$ \\
\hline & & in re & $\begin{array}{r}\text { a toto } \\
\text { aparte } \\
\text { a genere } \\
\text { abspecie } \\
\text { a differentia } \\
\text { a proprio } \\
\text { a definitione } \\
\text { a nomine } \\
\text { ab initio } \\
\text { a multiplici appellatione } \\
\text { a progressione vel profectu } \\
\text { a perfectione vel a consummatione }\end{array}$ \\
\hline & & circa rem & $\begin{array}{r}\text { a simili } \\
\text { a dissimili } \\
\text { a pari } \\
\text { a contrario } \\
\text { ab inter se collidentibus per habitionem et } \\
\text { amissionem } \\
\text { a maiore ad minus } \\
\text { a minore ad maius } \\
\text { a praecedenti } \\
\text { ab eo quod simul est vel a coniunctis } \\
\text { a consequentibus }\end{array}$ \\
\hline & & post rem & $\begin{array}{l}\text { ab eventu } \\
\text { a iudicato }\end{array}$ \\
\hline & & & $\begin{array}{r}\text { a coniugatione vel a coniugatis } \\
\text { a qualitate } \\
\text { a quantitate } \\
\text { a coniunctis } \\
\text { a partitione }\end{array}$ \\
\hline & inartificialia & & $\begin{array}{r}\text { in praeiudicia } \\
\text { in rumores } \\
\text { in tormenta } \\
\text { in tabulas } \\
\text { in ius iurandum } \\
\text { in testes }\end{array}$ \\
\hline
\end{tabular}


Diagram 10: Boethius, De topicis differentiis (Themistii divisio)

\begin{tabular}{|c|c|c|}
\hline \multirow[b]{2}{*}{$\begin{array}{c}\text { Loci qui in quaestione } \\
\text { sunt positi }\end{array}$} & $\begin{array}{c}\text { qui ab terminorum substantia } \\
\text { ducuntur }\end{array}$ & $\begin{array}{r}\text { a definitione } \\
\text { a descriptione } \\
\text { a nominis intepretatione }\end{array}$ \\
\hline & $\begin{array}{c}\text { qui terminorum substantiam } \\
\text { consequuntur }\end{array}$ & $\begin{array}{r}\text { a toto } \\
\text { [vel genere } \\
\text { vel integro] } \\
\text { a partibus } \\
\text { [vel generis } \\
\text { vel integri] } \\
\text { a causis } \\
\text { [vel efficientibus } \\
\text { vel materia } \\
\text { vel fine } \\
\text { vel forma] } \\
\text { a generationibus } \\
\text { a corruptionibus } \\
\text { ab usibus } \\
\text { a communiter accidentibus }\end{array}$ \\
\hline $\begin{array}{l}\text { Loci qui assumuntur } \\
\quad \text { extrinsecus }\end{array}$ & & $\begin{array}{r}\text { a rei iudicio } \\
\text { a similibus } \\
\text { [vel in qualitate } \\
\text { vel in quantitate] } \\
\text { a maiore } \\
\text { a minore } \\
\text { ab oppositis } \\
\text { [vel contraris } \\
\text { vel relativis } \\
\text { vel secundum privationem et habitum } \\
\text { vel secundum affirmationemet } \\
\text { negationem] } \\
\text { a proportione } \\
\text { a transumptione }\end{array}$ \\
\hline Loci medii & & $\begin{array}{r}\text { a casu } \\
\text { a coniugatis } \\
\text { a divisione }\end{array}$ \\
\hline
\end{tabular}


Diagram 11: Boethius, De topicis differentiis (Ciceronis divisio)

\begin{tabular}{|c|c|c|}
\hline \multirow[b]{2}{*}{$\begin{array}{c}\text { Loci qui in ipso haerent } \\
\text { de quo agitur }\end{array}$} & in ipso & $\begin{array}{r}\text { a toto } \\
\text { a partibus } \\
\text { a nota }\end{array}$ \\
\hline & $\begin{array}{c}\text { ab his quae sunt affecta } \\
\text { ad ea de quibus } \\
\text { quaeritur }\end{array}$ & $\begin{array}{r}\text { a coniugatis } \\
\text { a genere } \\
\text { a forma } \\
\text { a similitudine } \\
\text { a differentia } \\
\text { a contrario } \\
\text { ab adiunctiis } \\
\text { ab antecedentibus } \\
\text { a consequentibus } \\
\text { a repugnantibus } \\
\text { a causis } \\
\text { ab effectis } \\
\text { a comparatione maiorum } \\
\text { vel minorum } \\
\text { vel parium }\end{array}$ \\
\hline $\begin{array}{c}\text { Loci qui assumuntur } \\
\text { extrinsecus }\end{array}$ & & a rei iudicio \\
\hline
\end{tabular}

Diagram 12: See Boethius, De topicis differentiis, III, viI, 23, 1204C, p. 67, 12-31.

\begin{tabular}{|c|c|}
\hline M. Tullii divisio & Themistii divisio \\
\hline a toto & a substantia, id est a definitione \\
\hline a partium enumeratione & a divisione \\
\hline a notatione & a nominis interpretatione \\
\hline a coniugatis & a coniugatis \\
\hline a genere & a toto \\
\hline a forma & a parte id est a specie \\
\hline a similitudine & a similitudine \\
\hline a differentia & a toto \\
\hline a contrario & vel a parte \\
\hline ab adiunctis & ab oppositis \\
\hline ab antecedentibus & a communiter accidentibus \\
\hline a consequentibus & mixti cum pluribus \\
\hline a repugnantibus & ab oppositis \\
\hline ab efficientibus & a causis \\
\hline ab effectis & a fine \\
\hline a comparatione maiorum & a maiore \\
\hline a comparatione minorum & a minore \\
\hline a comparatione parium & a simili \\
\hline a rei iudicio & a rei iudicio \\
\hline
\end{tabular}




\section{Diagram 13}

\begin{tabular}{|c|c|}
\hline Themistii divisio & Ciceronis divisio \\
\hline M. Tullii divisio & Themistii divisio \\
\hline a definitione & $\begin{array}{c}\text { a toto } \\
\text { vel ab antecedentibus } \\
\text { vel a consequentibus }\end{array}$ \\
\hline a descriptione & $\begin{array}{c}\text { a genere } \\
\text { vel ab antecedentibus } \\
\text { vel a consequentibus }\end{array}$ \\
\hline a nominis interpretatione & $\begin{array}{c}\text { a notatio } \\
\text { vel ab antecedentibus } \\
\text { vel a consequentibus }\end{array}$ \\
\hline a toto & $\begin{array}{c}\text { a genere } \\
\text { vel ab antecedentibus } \\
\text { vel a consequentibus }\end{array}$ \\
\hline \multicolumn{2}{|l|}{ a partibus } \\
\hline a causis & $\begin{array}{c}\text { ab efficientibus causis } \\
\text { vel ab antecedentibus } \\
\text { vel a consequentibus }\end{array}$ \\
\hline $\begin{array}{l}\text { a generationibus } \\
\text { id est ab effectibus }\end{array}$ & $\begin{array}{c}\text { ab efficientibus causis } \\
\text { vel ab effectis }\end{array}$ \\
\hline a corruptionibus & ab efficientibus causis \\
\hline ab usibus & $\begin{array}{c}\text { ab efficientibus causis } \\
\text { vel } a b \text { effectis }\end{array}$ \\
\hline a communiter accidentibus & $\begin{array}{c}\text { ab adiunctis } \\
\text { vel ab antecedentibus } \\
\text { vel a consequentibus }\end{array}$ \\
\hline a rei iudicio & a rei iudicio \\
\hline a similibus & a comparatione parium \\
\hline a maiore & a comparatione maiorum \\
\hline a minore & a comparatione minorum \\
\hline ab oppositis & a repugnantibus \\
\hline a proportione & a similibus \\
\hline a transumptione & $\begin{array}{c}\text { a comparatione maiorum } \\
\text { vel minorum } \\
\text { vel parium }\end{array}$ \\
\hline a coniugatis & $\begin{array}{c}\text { a coniugatis } \\
\text { vel ab antecedentibus } \\
\text { vel a consequentibus }\end{array}$ \\
\hline a divisione & a partium enumeratione \\
\hline
\end{tabular}


Diagram 14: Boethius, De topicis differentiis (Themistii divisio: loci dialectici et rhetorici)

\begin{tabular}{|c|c|c|c|c|c|}
\hline \multicolumn{3}{|c|}{ Loci qui in quaestione sunt positi } & $\begin{array}{c}\text { Loci qui assumuntur } \\
\text { extrinsecus }\end{array}$ & \multicolumn{2}{|c|}{ Loci medii } \\
\hline \multicolumn{2}{|c|}{$\begin{array}{c}\text { Loci qui ab } \\
\text { terminorum } \\
\text { substantia } \\
\text { ducuntur }\end{array}$} & $\begin{array}{c}\text { Loci qui } \\
\text { terminorum } \\
\text { substantiam } \\
\text { consequuntur }\end{array}$ & & & \\
\hline \multicolumn{2}{|c|}{ a definitione } & $\begin{array}{c}\text { a toto } \\
\text { vel genere } \\
\text { vel integro }\end{array}$ & a rei iudicio & \multicolumn{2}{|c|}{ a casu } \\
\hline \multicolumn{2}{|c|}{ a descriptione } & $\begin{array}{l}\text { a partibus } \\
\text { vel generis } \\
\text { vel integri } \\
\end{array}$ & $\begin{array}{c}\text { a similibus } \\
\text { vel in qualitate } \\
\text { vel in quantitate }\end{array}$ & \multicolumn{2}{|c|}{ a coniugatis } \\
\hline \multicolumn{2}{|c|}{$\begin{array}{c}\text { a nominis } \\
\text { interpretatione }\end{array}$} & $\begin{array}{c}\text { a causis } \\
\text { vel efficientibus } \\
\text { vel materia } \\
\text { vel fine } \\
\text { vel forma } \\
\end{array}$ & a maiore & \multicolumn{2}{|c|}{ a divisione } \\
\hline & \multicolumn{2}{|c|}{ a generationibus } & a minore & & \\
\hline & \multicolumn{2}{|c|}{ a corruptionibus } & $\begin{array}{c}\text { ab oppositis } \\
\text { vel contrariis } \\
\text { vel relativis } \\
\text { vel secundum privationem et } \\
\text { habitum } \\
\text { vel secundum affirmationem } \\
\text { et negationem } \\
\end{array}$ & & \\
\hline & \multicolumn{2}{|c|}{ ab usibus } & a proportione & & \\
\hline & \multicolumn{2}{|c|}{$\begin{array}{c}\text { a communiter } \\
\text { accidentibus } \\
\end{array}$} & a transumptione & & \\
\hline \multicolumn{3}{|c|}{ Continentia cum ipso negotio } & Consecutio & In gestione negotii & Adiuncta negotio \\
\hline $\begin{array}{c}\text { Quis } \\
\text { (attributa } \\
\text { personae) }\end{array}$ & $\begin{array}{c}\text { Quid } \\
\text { (attributa } \\
\text { negotii) }\end{array}$ & \multirow[t]{11}{*}{$\begin{array}{c}\text { Cur } \\
\text { (attributa } \\
\text { negotii) }\end{array}$} & $\begin{array}{l}\text { Id quod factum est quo } \\
\text { nomine appellari conveniat }\end{array}$ & $\begin{array}{c}\text { Quando } \\
\text { (attributa negotii) } \\
\text { in tempus } \\
\text { in occasionem }\end{array}$ & genus \\
\hline nomen & $\begin{array}{c}\text { in } \\
\text { summam } \\
\text { facti }\end{array}$ & & \multirow{2}{*}{$\begin{array}{c}\text { Qui sunt auctores eius facti } \\
\text { et inventionis comprobatores } \\
\text { atque aemuli }\end{array}$} & $\begin{array}{c}\text { ubi } \\
\text { vel locus }\end{array}$ & species \\
\hline natura & $\begin{array}{c}\text { post } \\
\text { fucturn }\end{array}$ & & & & simile \\
\hline victus & dum fit & & \multirow[t]{2}{*}{$\begin{array}{c}\text { Quae eius rei sit lex, } \\
\text { consuetudo, pactio, iudicium, } \\
\text { scientia, artificium }\end{array}$} & & eventus \\
\hline fortuna & $\begin{array}{c}\text { ante } \\
\text { factum }\end{array}$ & & & & contrarium \\
\hline studium & & & \multirow{2}{*}{$\begin{array}{l}\text { Si natura eius evenire vulgo } \\
\text { soleat an insolenter et raro }\end{array}$} & & maius magnum \\
\hline casus & & & & & minus magnum \\
\hline affectio & & & & & aeque magnum \\
\hline habitus & & & Utrum homines id sua & & \\
\hline consilium & & & offendere in his consueverint & & disparatum \\
\hline $\begin{array}{c}\text { facta } \\
\text { orationes }\end{array}$ & & & & & \\
\hline
\end{tabular}




\section{Diagram 15: Boethius, De topicis differentiis (Themistii divisio)}

\begin{tabular}{|c|c|c|c|c|c|}
\hline \multicolumn{4}{|c|}{ Loci qui in quaestione sunt positi } & \multirow[t]{2}{*}{$\begin{array}{c}\text { Loci qui assumuntur } \\
\text { extrinsecus }\end{array}$} & \multirow[t]{2}{*}{ Loci medii } \\
\hline Loci qu & $\begin{array}{l}\text { terminorun } \\
\text { ducuntur }\end{array}$ & stantia & $\begin{array}{c}\text { Loci qui } \\
\text { terminorum } \\
\text { substantiam } \\
\text { consequuntur }\end{array}$ & & \\
\hline \multicolumn{3}{|c|}{ a definitione } & $\begin{array}{l}\text { a toto } \\
\text { vel genere } \\
\text { vel integro }\end{array}$ & a rei indicio & a casu \\
\hline \multicolumn{3}{|c|}{ a descriptione } & $\begin{array}{l}\text { a partibus } \\
\text { vel generis } \\
\text { vel integri }\end{array}$ & $\begin{array}{c}\text { a similibus } \\
\text { vel in qualitate } \\
\text { vel in quantitate }\end{array}$ & a coniugatis \\
\hline \multicolumn{3}{|c|}{ a nominis interpretatione } & $\begin{array}{c}\text { a causis } \\
\text { vel efficientibus } \\
\text { vel materia } \\
\text { vel fine } \\
\text { vel forma } \\
\end{array}$ & a maiore & a divisione \\
\hline \multirow{5}{*}{\multicolumn{3}{|c|}{ Continentia cum ipso negotio }} & a generationibus & a minore & \\
\hline & & & a corruptionibus & $\begin{array}{c}\text { ab oppositis } \\
\text { vel contrariis } \\
\text { vel relativis } \\
\text { vel secundum privationem et } \\
\text { habitum } \\
\text { vel secundum affirmationem et } \\
\text { negationem }\end{array}$ & \\
\hline & & & ab usibus & a proportione & \\
\hline & & & $\begin{array}{l}\text { a communiter } \\
\text { accidentibus }\end{array}$ & a transumptione & \\
\hline & & & In gestione negotii & Consecutio & Adiuncta negotio \\
\hline $\begin{array}{c}\text { Quis } \\
\text { (attributa } \\
\text { personae) }\end{array}$ & $\begin{array}{c}\text { Quid } \\
\text { (attributa } \\
\text { negotii) }\end{array}$ & $\begin{array}{c}\text { Cur } \\
\text { (attributa } \\
\text { negotii) }\end{array}$ & \multirow{2}{*}{$\begin{array}{c}\text { Quando } \\
\text { (attributa negotii) } \\
\text { in tempus } \\
\text { in occasionem }\end{array}$} & $\begin{array}{c}\text { Id quod factum est quo nomine } \\
\text { appellari conveniat }\end{array}$ & genus \\
\hline nomen & $\begin{array}{l}\text { in summam } \\
\text { facti }\end{array}$ & & & $\begin{array}{c}\text { Qui sunt auctores eius facti et } \\
\text { inventionis comprobatores } \\
\text { atque aemuli }\end{array}$ & species \\
\hline natura & post factum & & $\begin{array}{c}u b i \\
\text { vel locus }\end{array}$ & $\begin{array}{c}\text { Quae eius rei sit lex, } \\
\text { consuetudo, pactio, iudicium, } \\
\text { scientia, artificium }\end{array}$ & simile \\
\hline victus & dum fit & & $\begin{array}{l}\text { quomodo } \\
\text { vel modus }\end{array}$ & $\begin{array}{l}\text { Si natura eius evenire vulgo } \\
\text { soleat an insolenter et raro }\end{array}$ & eventus \\
\hline \multirow{2}{*}{ fortuna } & \multirow{2}{*}{ ante factum } & & \multirow{2}{*}{$\begin{array}{l}\text { quibus auxiliis } \\
\text { vel facultas }\end{array}$} & \multirow{2}{*}{$\begin{array}{c}\text { Utrum homines id sua } \\
\text { auctoritate comprobare an } \\
\text { offendere in his consueverint }\end{array}$} & contrarium \\
\hline & & & & & maius magnum \\
\hline studium & & & & & \multirow{3}{*}{ minus magnum } \\
\hline casus & & & & & \\
\hline affectio & & & & & \\
\hline habitus & & & & & \multirow[b]{2}{*}{ aeque magnum } \\
\hline consilium & & & & & \\
\hline facta & & & & & \\
\hline orationes & & & & & disparatum \\
\hline
\end{tabular}


Diagram 16: Boethius, De topicis differentiis (Ciceronis divisio)

\begin{tabular}{|c|c|c|c|c|c|}
\hline \multicolumn{5}{|c|}{ Loci qui in ipso haerent de quo agitur } & \multirow[t]{2}{*}{$\begin{array}{l}\text { oci qui assumuntur } \\
\text { extrinsecus }\end{array}$} \\
\hline \multicolumn{3}{|c|}{ a partibus } & a nota & $\begin{array}{c}\text { Loci ab his quae sunt } \\
\text { affecta ad ea de quibus } \\
\text { quaeritur }\end{array}$ & \\
\hline & & & & a coniugatis & \\
\hline & & & & a genere & \\
\hline & & & & a forma & \\
\hline & & & & a similitudine & \\
\hline & & & & a differentia & \\
\hline & & & & a contrario & \\
\hline & & & & $a b$ adiunctis & \\
\hline & & & & ab antecedentibus & \\
\hline & & & & a consequentibus & \\
\hline & & & & a repugnantibus & \\
\hline & & & & a causis & \\
\hline & & & & $a b$ effectis & \\
\hline & & & & $\begin{array}{c}\text { a comparatione maiorum } \\
\text { vel minorum } \\
\text { vel parium }\end{array}$ & \\
\hline Contine & ntia cum ipso & negotio & $\begin{array}{c}\text { In gestione } \\
\text { negotii }\end{array}$ & Adiuncta negotio & Consecutio \\
\hline $\begin{array}{c}\text { Quis } \\
\text { (attributa } \\
\text { personae) }\end{array}$ & $\begin{array}{c}\text { Quid } \\
\text { (attributa } \\
\text { negotii) }\end{array}$ & $\begin{array}{c}\text { Cur } \\
\text { (attributa } \\
\text { negotii) }\end{array}$ & $\begin{array}{l}\text { Quando } \\
\text { (Attributa } \\
\text { negotii) }\end{array}$ & genus & $\begin{array}{c}\text { Id quod factum est quo } \\
\text { nomine appellari } \\
\text { conveniat }\end{array}$ \\
\hline nomen & $\begin{array}{l}\text { in summam } \\
\text { facti }\end{array}$ & & $\begin{array}{l}\text { in tempus } \\
\text { in } \\
\text { occasio- } \\
\text { nem }\end{array}$ & species & $\begin{array}{c}\text { Qui sunt auctores eius } \\
\text { facti et inventionis } \\
\text { comprobatores atque } \\
\text { aemuli }\end{array}$ \\
\hline natura & post factum & & $\begin{array}{c}\text { ubi } \\
\text { vel locus }\end{array}$ & simile & $\begin{array}{l}\text { Quae eius rei sit lex, } \\
\text { consuetudo, pactio, } \\
\text { iudicium, scientia, } \\
\text { artificium }\end{array}$ \\
\hline victus & dum fit & & $\begin{array}{l}\text { quomodo } \\
\text { vel modus }\end{array}$ & eventus & $\begin{array}{c}\text { Si natura eius evenire } \\
\text { vulgo soleat an } \\
\text { insolenter et raro }\end{array}$ \\
\hline fortuna & $\begin{array}{c}\text { ante } \\
\text { factum }\end{array}$ & & $\begin{array}{c}\text { quibus } \\
\text { auxiliis } \\
\text { vel facultas }\end{array}$ & contrarium & $\begin{array}{c}\text { Utrum homines id sua } \\
\text { auctoritate comprobare } \\
\text { an offendere in his } \\
\text { consueverint }\end{array}$ \\
\hline studium & & & & & \\
\hline casus & & & & maius & \\
\hline affectio & & & & & \\
\hline habitus & & & & minu & \\
\hline consilium & & & & monus & \\
\hline facta & & & & aeque magnum & \\
\hline orationes & & & & disparatum & \\
\hline
\end{tabular}




\section{Diagram 17: Boethius, De topicis differentiis (Ciceronis divisio)}

\begin{tabular}{|c|c|c|c|c|c|}
\hline \multicolumn{5}{|c|}{ Loci qui in ipso haerent de quo agitur } & $\begin{array}{c}\text { Loci qui assumuntur extrinse- } \\
\text { cus }\end{array}$ \\
\hline a toto & a partibus & a nota & \multicolumn{2}{|c|}{$\begin{array}{c}\text { Loci ab his quae sunt } \\
\text { affecta } \\
\text { ad ea de quibus quaeritur }\end{array}$} & a rei iudicio \\
\hline & & & \multicolumn{2}{|c|}{ a coniugatis } & \\
\hline & & & \multicolumn{2}{|c|}{ a genere } & \\
\hline & & & \multicolumn{2}{|c|}{ a forma } & \\
\hline & & & \multicolumn{2}{|c|}{ a similitudine } & \\
\hline & & & \multicolumn{2}{|c|}{ a differentia } & \\
\hline & & & \multicolumn{2}{|c|}{ a contrario } & \\
\hline & & & \multicolumn{2}{|c|}{$a b$ adiunctis } & \\
\hline & & & \multicolumn{2}{|c|}{ ab antecedentibus } & \\
\hline & & & \multicolumn{2}{|c|}{ a consequentibus } & \\
\hline & & & \multicolumn{2}{|c|}{ a repugnantibus } & \\
\hline & & & \multicolumn{2}{|c|}{ a causis } & \\
\hline & & & \multicolumn{2}{|c|}{$a b$ effectis } & \\
\hline & & & \multicolumn{2}{|c|}{$\begin{array}{c}\text { a comparatione maiorum } \\
\text { vel minorum } \\
\text { vel parium }\end{array}$} & \\
\hline \multicolumn{3}{|c|}{ Continentia cum ipso negotio } & $\begin{array}{l}\text { In gestione } \\
\text { negotii }\end{array}$ & $\begin{array}{c}\text { Adiuncta } \\
\text { negotio }\end{array}$ & Consecutio \\
\hline $\begin{array}{c}\text { Quis } \\
\text { (dttributa } \\
\text { personae }\end{array}$ & $\begin{array}{l}\text { Quid } \\
\text { (attributa } \\
\text { negotii) }\end{array}$ & $\begin{array}{c}\text { Cur } \\
\text { (attributa } \\
\text { negotii) }\end{array}$ & \multirow[t]{2}{*}{$\begin{array}{l}\text { Quando } \\
\text { (Attributa } \\
\text { negotii) }\end{array}$} & genus & $\begin{array}{c}\text { Quo nomine appellari } \\
\text { conveniat, quod factum est }\end{array}$ \\
\hline nomen & $\begin{array}{l}\text { in summam } \\
\text { facti }\end{array}$ & & & species & $\begin{array}{c}\text { Qui sunt principes et inventores, } \\
\text { qui denique auctoritatis eius et } \\
\text { inventionis comprobatores atque } \\
\text { aemuli }\end{array}$ \\
\hline natura & post factum & & $\begin{array}{c}\text { ubi } \\
\text { vel locus }\end{array}$ & simile & $\begin{array}{c}\text { Quae de ea re aut eius rei sit lex, } \\
\text { consuetudo, pactio, iudicium, } \\
\text { scientia, artificium }\end{array}$ \\
\hline victus & dum fit & & $\begin{array}{l}\text { quomodo } \\
\text { vel modus }\end{array}$ & eventus & $\begin{array}{l}\text { Natura eius evenire vulgo soleat } \\
\text { an insolenter et raro }\end{array}$ \\
\hline fortuna & ante factum & & $\begin{array}{c}\text { quibus } \\
\text { auxiliis } \\
\text { vel facultas }\end{array}$ & contrarium & $\begin{array}{c}\text { Utrum homines id sua } \\
\text { auctoritate comprobare an } \\
\text { offendere in iis consueverint }\end{array}$ \\
\hline studium & & & & \multirow{3}{*}{ maius } & \\
\hline casus & & & & & \\
\hline affectio & & & & & \\
\hline habitus & & & & minus & \\
\hline consilium & & & & aeque & \\
\hline facta & & & & magnum & \\
\hline orationes & & & & disparatum & \\
\hline
\end{tabular}


Diagram 18: Cassiodorus, Institutiones

\begin{tabular}{|c|c|c|}
\hline & & $\begin{array}{r}\text { a toto } \\
\text { a partium enuratione } \\
\text { a nota }\end{array}$ \\
\hline $\begin{array}{c}\text { qui in ipso } \\
\text { de quo agitur haerent }\end{array}$ & $\begin{array}{l}\text { ex his rebus quae } \\
\text { quodammodoaffectae sunt } \\
\text { ad id de quo quaeritur }\end{array}$ & $\begin{array}{r}\text { a coniugata } \\
\text { a genere } \\
\text { a forma generis } \\
\text { a similitudine } \\
\text { a differentia } \\
\text { a contrario } \\
\text { ab adiunctiis } \\
\text { ab antecedentibus } \\
\text { a consequentibus } \\
\text { a repugnantibus } \\
\text { a causis } \\
\text { ab effectis } \\
\text { a comparatione maiorum } \\
\text { vel minorum } \\
\text { vel parium }\end{array}$ \\
\hline $\begin{array}{l}\text { qui assumuntur } \\
\text { extrinsecus }\end{array}$ & a rei iudicio & $\begin{array}{r}\text { ex persona } \\
\text { ex natura auctoritate } \\
\text { [in virtute] } \\
\text { ex temporis auctoritate } \\
\text { [ab ingenio } \\
\text { ab opibus } \\
\text { ab aetate } \\
\text { a fortuna } \\
\text { ab arte } \\
a b \text { usu } \\
\text { a necessitate } \\
\text { a concursio rerum fortuitarum] } \\
\text { a dictis fatisque maiorum } \\
\text { a tormentis }\end{array}$ \\
\hline
\end{tabular}




\section{Diagram 19: Isidorus, Etymologiae}

\begin{tabular}{|c|c|c|}
\hline & & $\begin{array}{r}\text { a toto } \\
\text { a partium enuratione } \\
\text { a nota }\end{array}$ \\
\hline $\begin{array}{c}\text { qui in ipso } \\
\text { de quo agitur haerent }\end{array}$ & $\begin{array}{c}\text { quae dicuntur effecta, } \\
\text { quae quodammadoex rebus aliis } \\
\text { tracta noscuntur }\end{array}$ & $\begin{array}{r}\text { a coniugata } \\
\text { a genere } \\
\text { a forma generis } \\
\text { a similitudine } \\
\text { a differentia } \\
\text { a contrario } \\
\text { ab adiunctios } \\
\text { ab antecedentibus } \\
\text { a consequentibus } \\
\text { a repugnantibus } \\
\text { a causis } \\
\text { ab effectis } \\
\text { a comparatione maiorum } \\
\text { vel minorum } \\
\text { vel parium }\end{array}$ \\
\hline $\begin{array}{l}\text { qui adsumuntur } \\
\text { extrinsecus }\end{array}$ & testimonium & $\begin{array}{r}\text { expersona } \\
\text { ex natura auctoritate } \\
\text { ex temporibus auctoritate } \\
\text { ex dictis fatisque maiorum } \\
\text { ex tormentis }\end{array}$ \\
\hline
\end{tabular}

\section{Diagram 20: Alcuinus, De dialectica}

\begin{tabular}{|c|c|c|}
\hline & & $\begin{array}{r}\text { a toto } \\
\text { [vel a genere } \\
\text { vel ex multis partibus integrum] } \\
\text { a partibus } \\
\text { a fine }\end{array}$ \\
\hline $\begin{array}{l}\text { qui in ipso negotio } \\
\text { de quo agitur }\end{array}$ & ex rebus aliis tracta nascuntur & $\begin{array}{r}\text { a coniugata } \\
\text { a genere } \\
\text { a specie } \\
\text { a similitudine } \\
\text { a differentia } \\
\text { ex contrariis } \\
\text { a consequente } \\
\text { ab antecedentibus } \\
\text { ab adiunctis } \\
\text { a repugnantibus } \\
\text { a causis } \\
\text { ab effectis } \\
\text { a comparatione } \\
\text { [a maiore } \\
\text { vel a minore } \\
\text { vel a pari] }\end{array}$ \\
\hline qui assumuntur extrinsecus & & \\
\hline
\end{tabular}


Diagram 21: Anomymus, Dialectica

\begin{tabular}{|c|c|c|}
\hline \multirow[b]{2}{*}{ loci } & \multicolumn{2}{|r|}{$\begin{array}{r}\text { a toto } \\
\text { a parte } \\
\text { a nota }\end{array}$} \\
\hline & quae extrinsecus cognata sunt & $\begin{array}{r}\text { a coniugatis } \\
\text { a genere } \\
\text { a specie } \\
\text { a simili } \\
\text { a differentia } \\
\text { a contrariis } \\
\text { ab adiunctis } \\
\text { ab antecedentibus } \\
\text { a consequentibus } \\
\text { a repugnantibus } \\
\text { ab efficientibus rebus } \\
\text { ab effectis } \\
\text { a comparatione } \\
\text { [a maiore } \\
\text { a minore } \\
\text { a pari] }\end{array}$ \\
\hline & attributa ex personis & $\begin{array}{r}\text { nomen } \\
\text { natura } \\
\text { victum } \\
\text { fortuna } \\
\text { habitus } \\
\text { affectio } \\
\text { studiua } \\
\text { consilia } \\
\text { facta } \\
\text { casus } \\
\text { orationes }\end{array}$ \\
\hline & attributa ex negotiis & $\begin{array}{r}\text { continentia cum ipso negotiio } \\
\text { in gestione negotii } \\
\text { adiuncta negotio } \\
\text { quae gestum negotium consequentur }\end{array}$ \\
\hline
\end{tabular}




\section{Diagram 22: Garlandus COMPOTISTA, Dialectica}

\begin{tabular}{|c|r|}
\hline & $\begin{array}{r}\text { a diffinitione vel a toto } \\
\text { a descriptione vel a toto } \\
\text { a }\end{array}$ \\
a toto \\
[vel genere \\
vel integro] \\
a partibus \\
[vel generis \\
vel integri] \\
a causis \\
loci in ipso haerent de quo agitur \\
intepretatione vel a
\end{tabular}


Diagram 23: Garlandus Compotista, Dialectica

\begin{tabular}{|c|c|c|}
\hline $\begin{array}{c}\text { Loci qui in ipso herent } \\
\text { de quo queritur }\end{array}$ & a substantia & $\begin{array}{r}\text { a diffinitione vel a toto } \\
\text { a descriptione vel a toto } \\
\text { a nominis intepretatione vel a nota }\end{array}$ \\
\hline & $\begin{array}{l}\text { a consequentibus } \\
\text { substantiam }\end{array}$ & $\begin{array}{r}\text { a toto } \\
\text { [vel genere } \\
\text { vel integro ] } \\
\text { a partibus } \\
\text { [vel generis } \\
\text { vel integri] } \\
\text { a causis } \\
\text { [vel efficientibus } \\
\text { vel materia } \\
\text { vel forma } \\
\text { vel fine] } \\
\text { a generationibus } \\
\text { a corruptionibus } \\
\text { ab usibus } \\
\text { a communiter accidentibus }\end{array}$ \\
\hline $\begin{array}{l}\text { Loci extrinsecus } \\
\text { assumuntur }\end{array}$ & & $\begin{array}{r}\text { a rei iudicio } \\
\text { a simili } \\
\text { [in quantitate } \\
\text { vel in qualitate] } \\
\text { a maiore } \\
\text { a minore } \\
\text { ab oppositis } \\
\text { a transsumptione }\end{array}$ \\
\hline Loci medii & & $\begin{array}{l}\text { a coniugatis } \\
\text { a divisione }\end{array}$ \\
\hline
\end{tabular}

magnano@pul.it

Fecha de recepción: día 8 de febrero de 2015

Fecha de aceptación: día 9 de septiembre de 2015 